Prepared for the U.S. Department of Energy

under Contract DE-AC05-76RL01830

\title{
Baker-Barry Tunnel Lighting: Evaluation of a Potential GATEWAY Demonstrations Project
}

\author{
JR Tuenge
}

June 2011

Pacific Northwest

NATIONAL LABORATORY

Proudly Operated by Battelle Since 1965 


\title{
DISCLAIMER
}

This report was prepared as an account of work sponsored by an agency of the United States Government. Neither the United States Government nor any agency thereof, nor Battelle Memorial Institute, nor any of their employees, makes any warranty, express or implied, or assumes any legal liability or responsibility for the accuracy, completeness, or usefulness of any information, apparatus, product, or process disclosed, or represents that its use would not infringe privately owned rights. Reference herein to any specific commercial product, process, or service by trade name, trademark, manufacturer, or otherwise does not necessarily constitute or imply its endorsement, recommendation, or favoring by the United States Government or any agency thereof, or Battelle Memorial Institute. The views and opinions of authors expressed herein do not necessarily state or reflect those of the United States Government or any agency thereof.

\author{
PACIFIC NORTHWEST NATIONAL LABORATORY \\ operated by \\ BATTELLE \\ for the \\ UNITED STATES DEPARTMENT OF ENERGY \\ under Contract DE-AC05-76RL01830
}

Printed in the United States of America
Available to DOE and DOE contractors from the Office of Scientific and Technical Information,
P.O. Box 62, Oak Ridge, TN 37831-0062;
ph: (865) 576-8401
fax: $(865) 576-5728$
email: reports@adonis.osti.gov

\author{
Available to the public from the National Technical Information Service, \\ U.S. Department of Commerce, 5285 Port Royal Rd., Springfield, VA 22161 \\ ph: (800) 553-6847 \\ fax: (703) 605-6900 \\ email: orders@ntis.fedworld.gov \\ online ordering: http://www.ntis.gov/ordering.htm
}

This document was printed on recycled paper. 


\section{Baker-Barry Tunnel Lighting: Evaluation of a Potential GATEWAY Demonstrations Project}

JR Tuenge

June 2011

Prepared for

the U.S. Department of Energy

under Contract DE-AC05-76RL01830

Pacific Northwest National Laboratory

Richland, Washington 99352 



\section{Acronyms and Abbreviations}

$\begin{array}{ll}\text { AADT } & \text { Average Annual Daily Traffic } \\ \text { ANSI } & \text { American National Standards Institute } \\ \text { CCT } & \text { correlated color temperature } \\ \text { cd } & \text { candela(s) } \\ \text { CRI } & \text { color rendering index } \\ \text { DOE } & \text { U.S. Department of Energy } \\ \text { FLH } & \text { Office of Federal Lands Highway } \\ \text { HID } & \text { high-intensity discharge } \\ \text { HPS } & \text { high-pressure sodium } \\ \text { IES or IESNA } & \text { Illuminating Engineering Society of North America } \\ \text { IP } & \text { Ingress Protection } \\ \text { LED } & \text { light-emitting diode } \\ \text { NFPA } & \text { National Fire Protection Association } \\ \text { NEMA } & \text { National Electrical Manufacturers Association } \\ \text { NPS } & \text { National Park Service } \\ \text { lm } & \text { lumen(s) } \\ \text { lx } & \text { lux } \\ m^{2} & \text { square meter } \\ \text { PNNL } & \text { Pacific Northwest National Laboratory } \\ \text { SSL } & \text { solid-state lighting } \\ \text { W } & \text { watt(s) } \\ \text { Wh } & \text { Watt-hour(s) } \\ & \end{array}$





\section{Contents}

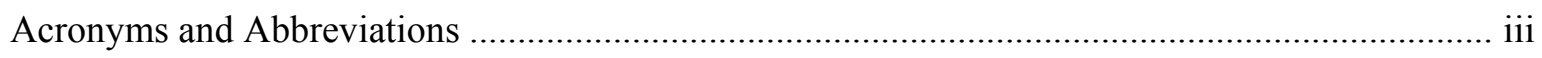

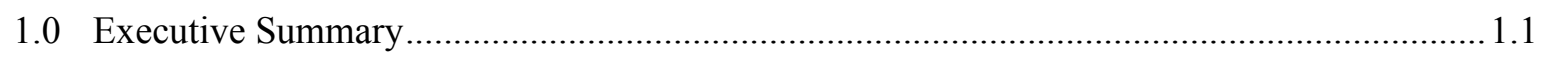

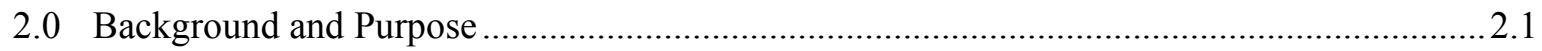

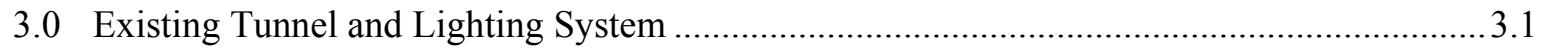

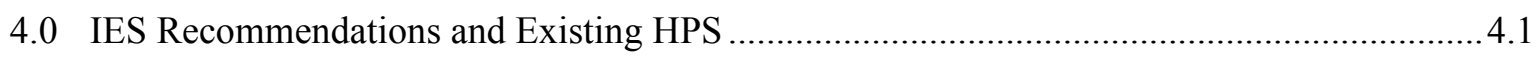

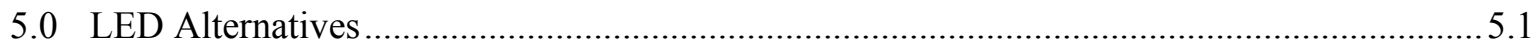

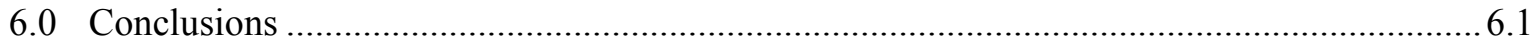

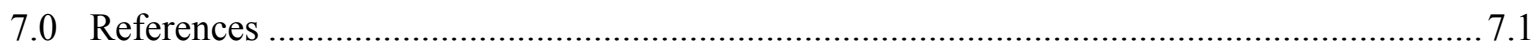

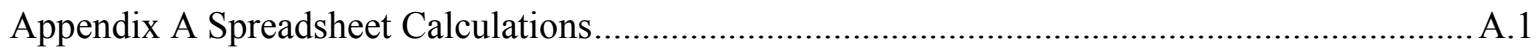

Appendix B Luminaire Data - Existing HPS …...................................................................... B.1

Appendix C Luminaire Data - LED Evaluated ...................................................................

Appendix D Luminaire Data - Additional LED Products Considered ........................................ D.1

Appendix E Notes Received from NPS on March 9, 2010 ........................................................ E.1 



\subsection{Executive Summary}

The U.S. Department of Energy (DOE) is evaluating the Baker-Barry Tunnel as a potential GATEWAY Demonstrations project for deployment of solid-state lighting (SSL) technology. The National Park Service (NPS) views this project as a possible proving ground and template for implementation of light-emitting diode (LED) luminaires in other NPS tunnels, thereby expanding the estimated $40 \%$ energy savings from $132 \mathrm{MWh} / \mathrm{yr}$ for this tunnel to a much larger figure nationally.

Most of the energy savings in this application is attributable to the instant-restrike capability of LED products and to their high tolerance for frequent on/off switching. Rather than brightly lighting both ends of the single-lane tunnel during the day (treating both as entrances), the traffic signals already used to determine the direction of traffic could also be utilized to reduce light levels at the tunnel exit. Some LED luminaires rival or outperform their high-intensity discharge (HID) counterparts in terms of efficacy, but options are limited, and smaller lumen packages preclude true one-for-one equivalence. However, LED products continue to improve in efficacy and affordability at a rate unmatched by other light source technologies; the estimated simple payback period of eight years (given a $\$ 0.17 / \mathrm{kWh}$ electricity rate and excluding both installation costs and maintenance savings) can be expected to improve with time. ${ }^{1}$

The proposed revisions to the existing high-pressure sodium (HPS) lighting system would require slightly increased controls complexity and significantly increased luminaire types and quantities. In exchange, substantial annual savings (from reduced maintenance and energy use) would be complemented by improved quantity and quality of illumination. Although more advanced lighting controls could offer additional savings, it is unclear whether such a system would prove cost-effective; this topic may be explored in future work.

\footnotetext{
${ }^{1}$ Detailed DOE SSL forecasts can be found at www.ssl.energy.gov/tech reports.html.
} 



\subsection{Background and Purpose}

In March 2010, GATEWAY performed a preliminary analysis of the existing high-pressure sodium (HPS) lighting system on behalf of NPS. This report supersedes the previous analysis by incorporating its contents and providing revised, updated, or expanded material as follows:

- Per documents received from NPS on April 28, 2010

- Estimated tunnel height revised from 17 to 16 feet

- Centerline of drivelane offset 18 inches from centerline of luminaires and tunnel

○ Widths revised as follows: 10.5 feet for drivelane, 3.5 feet for north bikelane, 4.5 feet for south bikelane

- Estimated daily traffic revised from greater than 2,400 to less than 2,400 vehicles

- Estimated distance from entrance to first (existing) energized luminaire encountered at night revised from 16.5 to 35 feet

- Per changes to the recently updated ANSI/IES RP-22

- Revised criteria for the transition zone gradient

- Revised wall illumination criteria

- Veiling luminance calculations corrected to exclude areas outside the interior zone

- Estimated surface reflectances revised

- Minimum ingress protection (IP) rating revised from 65 to 66 for power-wash cleaning

- Evaluation of alternative light-emitting diode (LED) luminaires

- Evaluation of illumination levels under emergency power

- Incorporation of simple traffic-signal-based on/off lighting controls

The potential for advanced lighting controls as a supplemental energy-savings measure may be detailed in a follow-up report. 



\subsection{Existing Tunnel and Lighting System}

The Baker-Barry Tunnel was constructed in 1918 in what is now the Golden Gate National Recreation Area. The tunnel allows Bunker Road to pass under Highway 101 and through a hill on the north side of the Golden Gate Bridge. According to a recent inspection by the Office of Federal Lands Highway, the tunnel is 2,690 feet long, 16 feet in height (approximately 15 feet clearance), and 20 feet wide, as indicated in Figure 3.1 (FLH 2002).

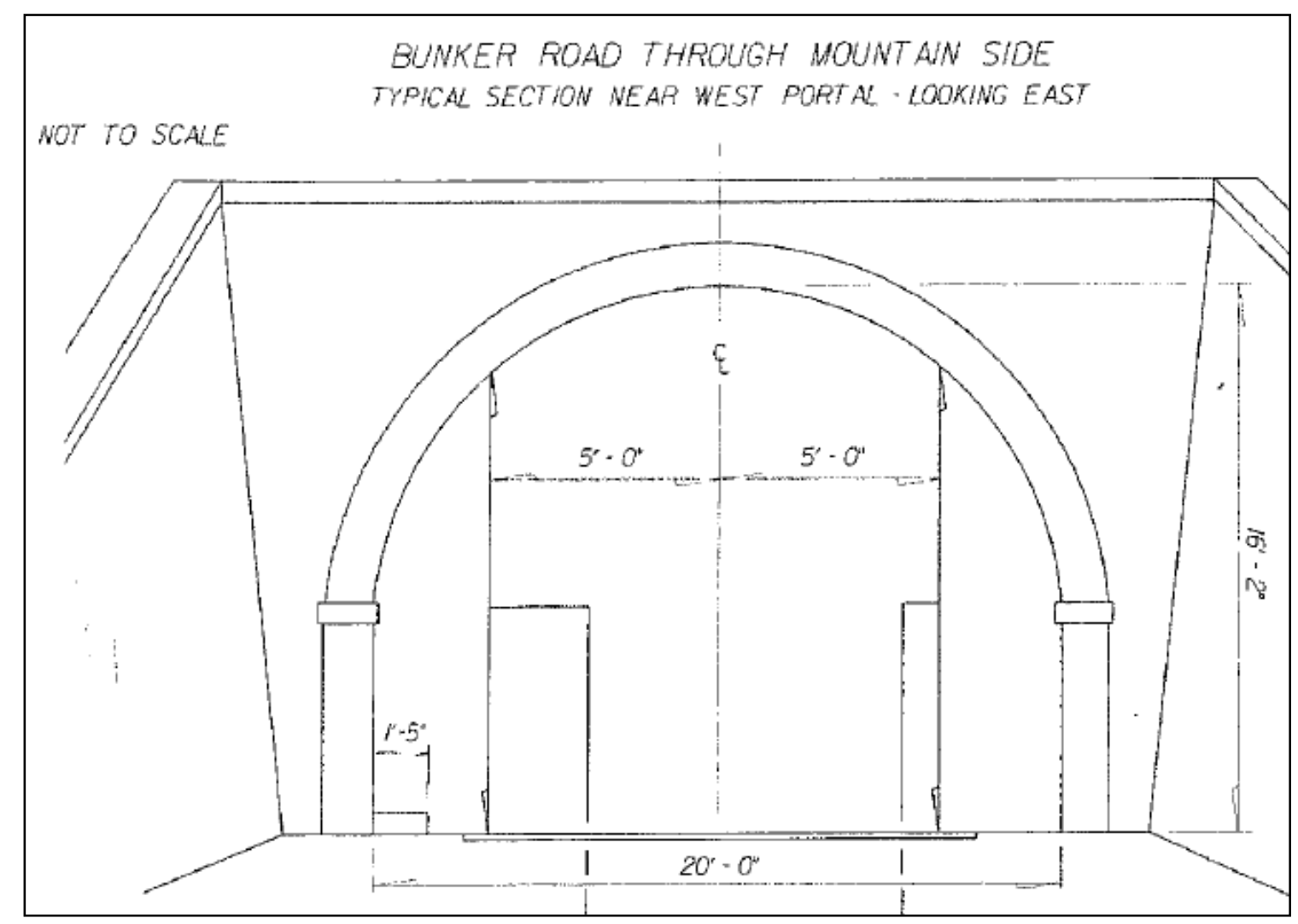

Figure 3.1. Tunnel cross-section (Image credit: FLH)

Separate construction drawings produced for NPS in 1993 indicate a tunnel length of 2,360 feet, consistent with analysis by GATEWAY indicating an approximate length of 2,346 feet (using satellite imagery from Google). It is assumed this NPS length measurement is accurate.

A single driving lane is bounded on either side by unprotected bicycle lanes. Posted speed limit is $25 \mathrm{mph}$ for both approaches and within the tunnel, with vehicular traffic flow running roughly NW to/from SE (aligning more closely with the East-West axis than with the North-South axis). The direction of one-way traffic reverses periodically via traffic signals at either end, as indicated in Figure 3.2. ${ }^{2}$ Elimination of oncoming traffic allows the tunnel to be classified as "divided," and the approach can be classified as "mountain" as illustrated by Figures 3.3 and 3.4. It appears neither of the two approaches to the tunnel is illuminated by pole-mounted luminaires. Average annual daily traffic (AADT) is

\footnotetext{
${ }^{2}$ Images captured using the Street View tool in Google Maps, for Bunker Road at Danes Drive.
} 
approximately 600 vehicles. Pavement surface is asphalt (assumed R3), and the walls and arched ceiling are concrete, for estimated ceiling/walls/pavement reflectances of 30/30/20. Average ambient temperature is approximately $14^{\circ} \mathrm{C}$ and maximum is approximately $40^{\circ} \mathrm{C}$. ${ }^{3}$ Tunnel and luminaires are periodically cleaned via hose-down.

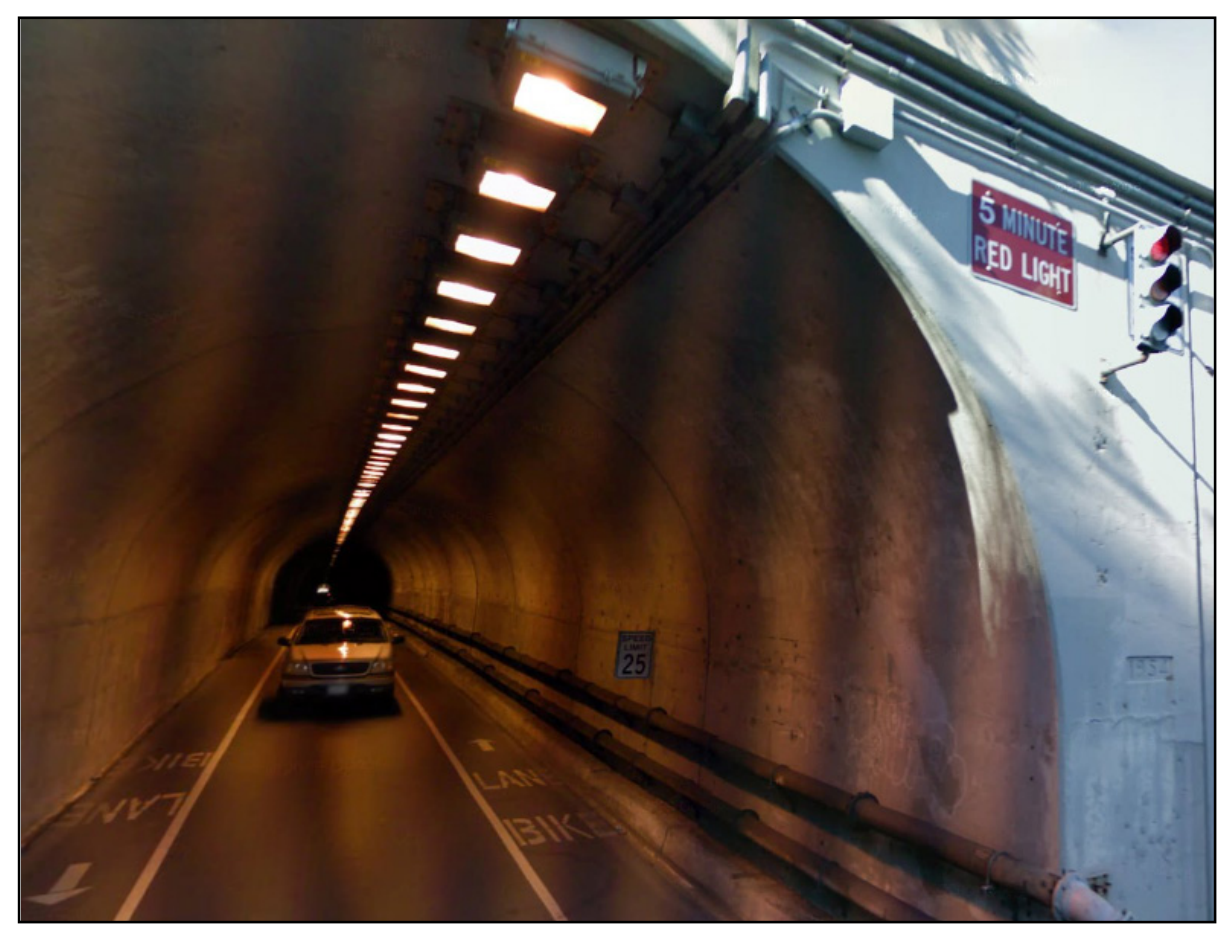

Figure 3.2. View from SE opening (Photo credit: Google)

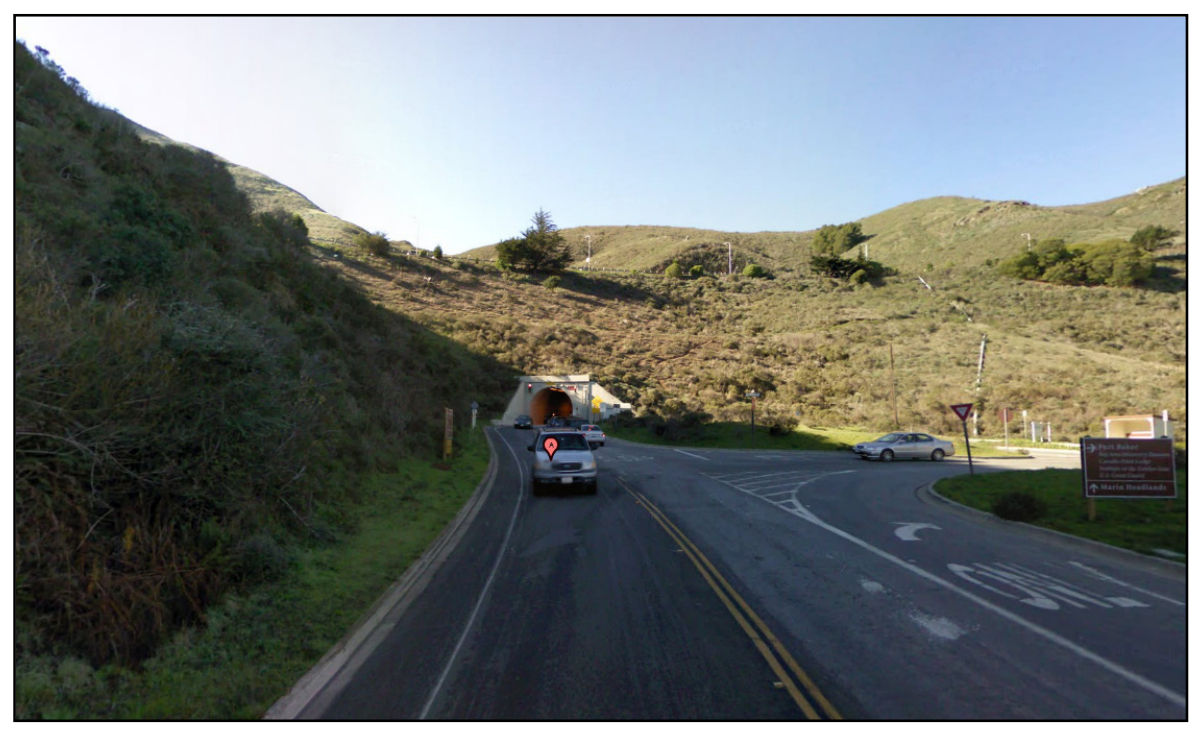

Figure 3.3. View of SE entrance to mountain tunnel (Photo credit: Google)

\footnotetext{
${ }^{3}$ From http://www.wrcc.dri.edu/htmlfiles/citycomptemp.html for San Fran Mission Dolore, accessed 2010-03-25.
} 


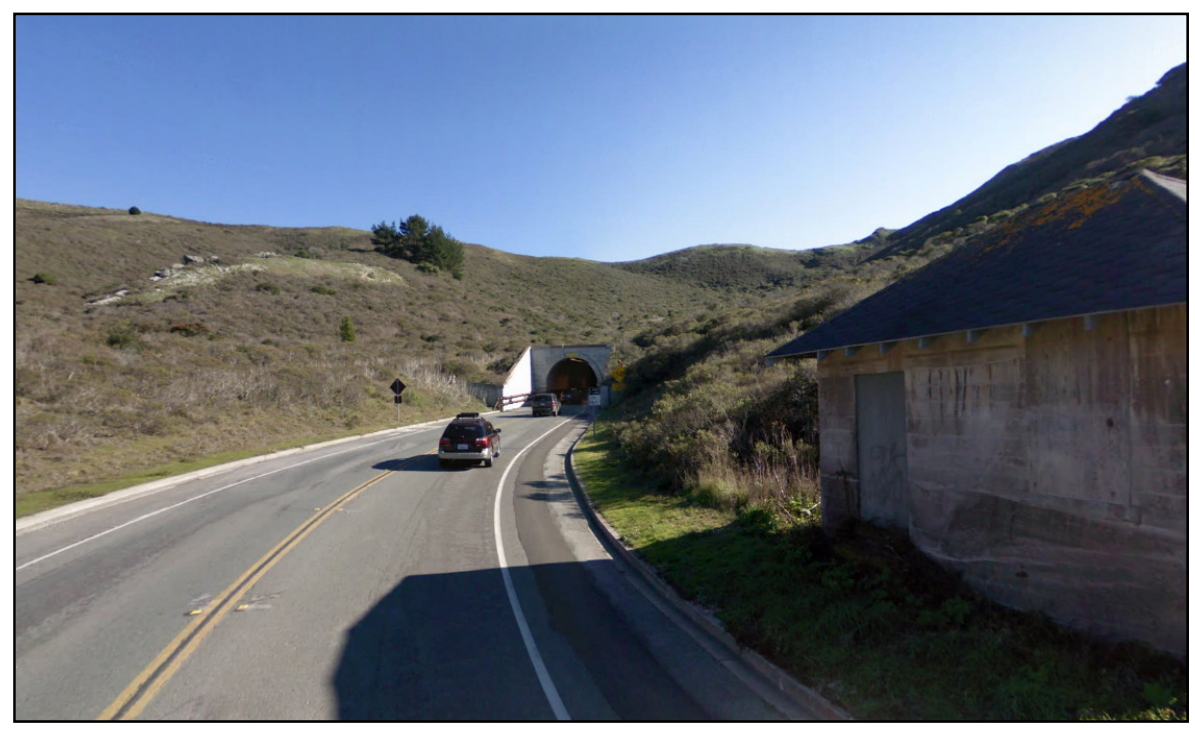

Figure 3.4. View of NW entrance, just past signal (Photo credit: Google)

The lighting system is divided into different zones for visual adaptation purposes. Upon entering the tunnel vehicles first pass through a 200 -foot threshold zone, followed by a 250 -foot transitional zone and 1,460-foot interior zone, and then another 250-foot transition zone and 200-foot threshold zone before exiting the tunnel. Luminaires on the emergency panel and panel L3 are operated continuously; all others are switched off at night. Existing luminaire types and operation are summarized in Table 3.1. Product cutsheets are also provided in Appendix B. Note that the cutsheet for the $100 \mathrm{~W}$ ballast specified by NPS indicates the product is not offered in $480 \mathrm{~V}$; this suggests that either two ballast types are used for the $100 \mathrm{~W}$ luminaires, or luminaire types indicated $480 \mathrm{~V}$ (phase to phase) may actually be wired $277 \mathrm{~V}$ (phase to neutral).

Table 3.1. Existing GE Lighting Solutions HPS luminaires

\begin{tabular}{|c|c|c|c|c|c|c|c|c|}
\hline Type & Catalog \# & $\begin{array}{l}\text { HPS } \\
\text { Lamp }\end{array}$ & $\begin{array}{c}\text { Initial } \\
\text { Output } \\
(\mathrm{lm})\end{array}$ & $\begin{array}{l}\text { Input } \\
\text { Power } \\
\text { (W) }\end{array}$ & $\begin{array}{c}\text { Initial } \\
\text { Efficacy } \\
(\operatorname{lm} / \mathrm{W})\end{array}$ & Location & Operation & Voltage \\
\hline H4D & TUN40S5 & $400 \mathrm{~W}$ & 39,616 & 464 & 85 & $\begin{array}{c}\text { Threshold } \\
\text { zone }\end{array}$ & $\begin{array}{c}\text { Daytime } \\
\text { only }\end{array}$ & $480 \mathrm{~V}$ \\
\hline $\mathrm{H} 2 \mathrm{D}$ & TUN25S5 & $250 \mathrm{~W}$ & 21,750 & 300 & 73 & $\begin{array}{l}\text { Transition } \\
\text { zone }\end{array}$ & $\begin{array}{c}\text { Daytime } \\
\text { only }\end{array}$ & $480 \mathrm{~V}$ \\
\hline H1D & TUN10S5 & $100 \mathrm{~W}$ & 7,379 & 130 & 57 & All zones & $\begin{array}{c}\text { Daytime } \\
\text { only }\end{array}$ & $480 \mathrm{~V}$ \\
\hline $\mathrm{H} 1 \mathrm{C}$ & TUN10S5 & $100 \mathrm{~W}$ & 7,379 & 130 & 57 & All zones & Continuous & $480 \mathrm{~V}$ \\
\hline $\mathrm{H} 1 \mathrm{E}$ & TUN10S5 & $100 \mathrm{~W}$ & 7,379 & 126 & 59 & All zones & $\begin{array}{l}\text { Continuous } \\
\text { and } \\
\text { Emergency }\end{array}$ & $277 \mathrm{~V}$ \\
\hline
\end{tabular}

A more detailed overview of the luminaire layout and circuiting is provided in Figure 3.5, where zones are represented by blocks, and rows within each block correspond to mode of operation. 


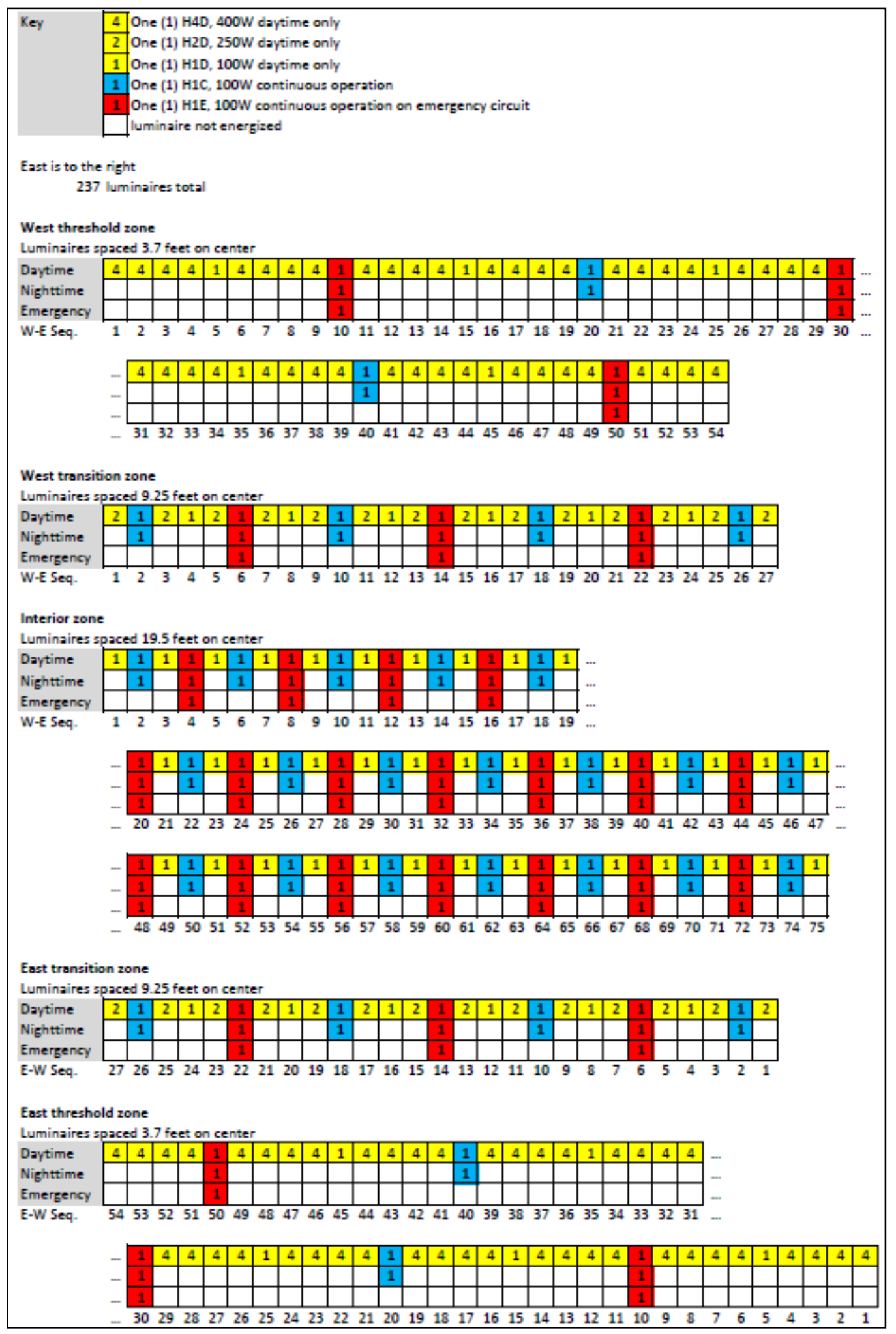

Figure 3.5. Existing luminaire layout and circuiting (derived from NPS drawings ${ }^{4}$ )

\footnotetext{
${ }^{4}$ According to Sheet E1 of the 1993 NPS set, every fourth luminaire in the threshold zone is 100W. It is assumed that in fact every fifth luminaire in this zone is $100 \mathrm{~W}$.
} 
The diagram can be more readily understood via some examples: Upon entering either entrance during the day, the first four luminaires encountered are $400 \mathrm{~W}$, followed by one $100 \mathrm{~W}$ luminaire; this series is repeated until the transition zone is reached ( 200 feet into the tunnel). Upon entering the tunnel, the $20^{\text {th }}$ luminaire encountered during the day is the first energized luminaire encountered at night. Similarly, the $10^{\text {th }}$ luminaire encountered during the day is the first energized luminaire encountered when the tunnel is running solely on emergency power.

The existing luminaires are available in a variety of distributions; it is not clear which specific distributions were installed. ${ }^{5}$ Given the periodically reversing flow of traffic and the location of luminaires over the single drive lane, a symmetric (as opposed to asymmetric) distribution would be appropriate. The only bilaterally symmetric distribution for which GE offers photometry is their $150 \mathrm{~W}$ STM optic, characterized in Figure 3.6 below and featuring $78 \%$ efficiency. The following calculations approximate $100 \mathrm{~W}, 250 \mathrm{~W}$, and $400 \mathrm{~W}$ by scaling down or up from the $150 \mathrm{~W}$ output based on rated lamp lumens. ${ }^{6}$ It is also not clear which ballasts were used for this project; this determines input wattage and efficacy. Lacking detailed luminaire specifications, initial luminaire efficacy is estimated at $59 \mathrm{~lm} / \mathrm{W}$ for 100W HPS, $71 \mathrm{~lm} / \mathrm{W}$ for $250 \mathrm{~W}$ HPS, and $85 \mathrm{~lm} / \mathrm{W}$ for $400 \mathrm{~W}$ HPS.

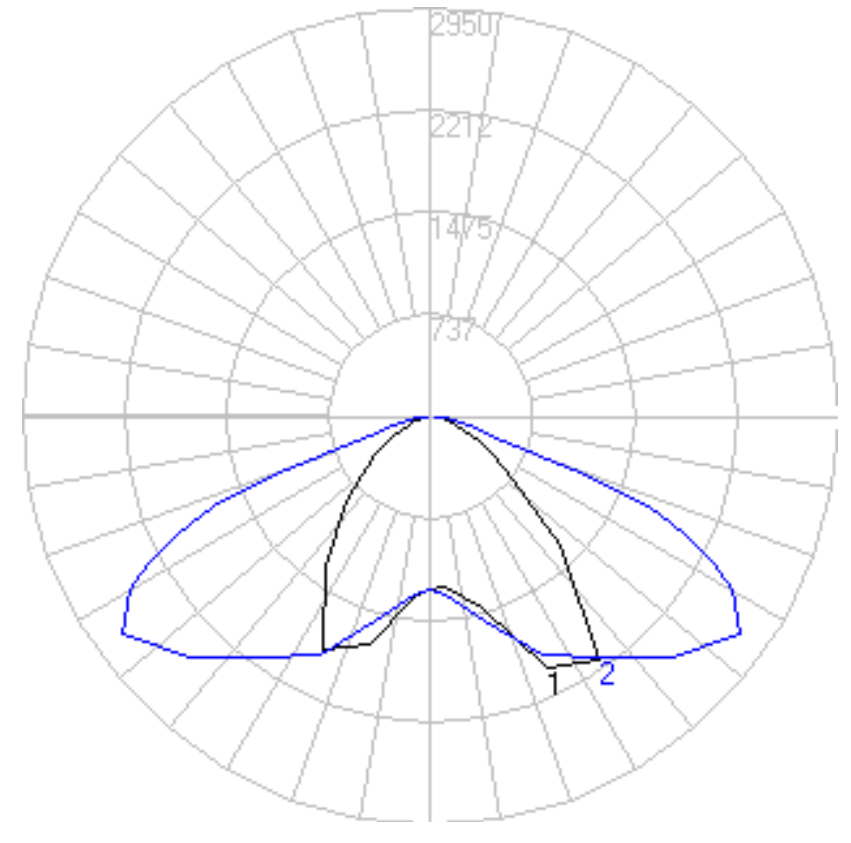

Figure 3.6. Elongated (elliptical) bilaterally symmetric intensity distribution for $150 \mathrm{~W}$ HPS, represented by candela traces for two vertical planes, one at 0-180 degrees horizontal (slightly asymmetric curve 1 in black) and 90-270 (curve 2 in blue).

\footnotetext{
${ }^{5}$ Note that the asymmetric CBM counter-beam optic indicated on the manufacturer cut-sheet is an example only. ${ }^{6}$ Analysis of the CBM optic, for which GE offers photometry at more than one wattage, suggests that optical efficiency may not be significantly influenced by lamp wattage.
} 
FY09 electric billing data for the tunnel lighting system (provided by NPS on April 13, 2010) is shown in Table 3.2.

Table 3.2. FY09 electrical energy cost

\begin{tabular}{|c|c|c|c|}
\hline Year & Month & $\mathrm{kWh} / \mathrm{mo}$ & \$/mo \\
\hline 2008 & 10 & 20,576 & $3,876.29$ \\
\cline { 2 - 2 } & 11 & 21,746 & $3,545.31$ \\
\cline { 2 - 2 } & 12 & 19,374 & $2,644.43$ \\
\hline 2009 & 1 & 20,320 & $2,751.59$ \\
\cline { 2 - 2 } & 2 & 22,499 & $3,022.98$ \\
\cline { 2 - 2 } & 3 & 20,763 & $2,846.09$ \\
\cline { 2 - 2 } & 4 & 25,091 & $3,474.24$ \\
\cline { 2 - 2 } & 5 & 23,680 & $4,242.11$ \\
\cline { 2 - 2 } & 6 & 26,015 & $5,216.83$ \\
\cline { 2 - 2 } & 7 & 28,491 & $5,712.96$ \\
\cline { 2 - 2 } & 8 & 24,900 & $4,993.36$ \\
\cline { 2 - 2 } & 9 & 24,511 & $4,916.00$ \\
\hline & Year total: & 277,966 & $47,242.19$ \\
\hline
\end{tabular}




\subsection{IES Recommendations and Existing HPS}

Given that there appear to be no pole-mounted luminaires outside the tunnel, the nighttime tunnel drivelane luminance is more than three times higher than the tunnel approach luminance; it is assumed that the traffic signals and low speed limit effectively mitigate this abrupt change from normal roadway illumination inside the tunnel to zero fixed lighting outside the tunnel.

Pertinent criteria are provided in IESNA RP-22 (tunnels) and RP-8 (bikeways). Luminaires should be listed for wet locations and have an ingress protection (IP) rating of 65 or better to exclude dirt and to be "protected against water jets" during hose-down cleaning; an IP-66 rating is recommended by GATEWAY to be "protected against powerful water jets" (NEMA 2002).

Luminaires should be arranged and controlled in a manner that does not result in luminaires disappearing over the windshield at a "frequency effect" of less than $4 \mathrm{~Hz}$ or greater than $11 \mathrm{~Hz}$; additional measures should be considered if drivers are exposed to more than 20 seconds of such flicker. Frequency effect is not expected to be problematic, as indicated in Table 4.1.

Table 4.1. Frequency effect and duration of exposure for $25 \mathrm{mph}$ traffic

\begin{tabular}{|c|c|c|c|c|c|c|c|}
\hline \multirow{2}{*}{ Parameter } & \multirow{2}{*}{ IES } & \multicolumn{2}{|c|}{ Threshold Zone } & \multicolumn{2}{c|}{ Transition Zone } & \multicolumn{2}{c|}{ Interior Zone } \\
\cline { 3 - 8 } & & Day & Night & Day & Night & Day & Night \\
\hline Spacing (ft) & n/a & 3.7 & 37 & 9.25 & 37 & 19.5 & 39 \\
\hline $\begin{array}{c}\text { Frequency } \\
\text { effect (Hz) }\end{array}$ & $\begin{array}{c}\leq 4 \\
\text { or } \\
\geq 11\end{array}$ & 9.9 & 1.0 & 4.0 & 1.0 & 1.9 & 0.9 \\
\hline Duration (s) & $\leq 20$ & \multicolumn{2}{|c|}{5.5} & \multicolumn{2}{|c|}{6.8} & & \multicolumn{2}{|c|}{39.8} \\
\hline
\end{tabular}

Drivelane photometric criteria and calculations are summarized in Table 4.2. Luminance calculation grids span the first quarter of each zone; the veiling luminance grid spans the second quarter of the lengthy interior zone in order to keep the driver in this zone (per IES).

A light loss factor (LLF) of 64\% was used for the existing HPS luminaires, based on a lamp lumen depreciation (LLD) factor of $85 \%$ and a luminaire dirt depreciation factor (LDD) of $75 \%$ for a "Moderate" level of smoke/dust generating activities nearby. ${ }^{7}$ This assumes group cleaning and relamping at approximately $70 \%$ of rated life (per IESNA DG-4-03), whereby daytime-only luminaires are serviced less frequently than continuous-operation luminaires. Spot relamping may be enabled by the traffic signals and low nighttime usage (possibly reducing the cost of tunnel closures), but this could compromise light levels and uniformity. ${ }^{8}$ Regular hose-down cleaning is assumed to occur every 4 years, based on 13 hours of operation per day for daytime-only luminaires.

\footnotetext{
${ }_{8}^{7}$ Assumes less than 600 micrograms of air particulate per cubic meter.

${ }^{8}$ According to the data in Table 3.2., system energy use in FY09 averaged 18\% below expected and was at best $1 \%$ below expected. This suggests that at any given moment during that period, approximately $18 \%$ of luminaires appear to have had failed lamps.
} 
Table 4.2. IES recommendations vs. estimated existing HPS illumination for the vehicular lane

\begin{tabular}{|c|c|c|c|c|c|c|c|c|c|}
\hline \multirow[t]{2}{*}{$\begin{array}{c}\text { Operating } \\
\text { Mode }\end{array}$} & \multirow[t]{2}{*}{ Zone } & \multicolumn{2}{|c|}{$\begin{array}{l}\text { Average Maintained } \\
\text { Roadway Luminance } \\
\qquad\left(\mathrm{cd} / \mathrm{m}^{2}\right)\end{array}$} & \multicolumn{2}{|c|}{$\begin{array}{l}\text { Roadway } \\
\text { Avg:Min } \\
\text { Uniformity }\end{array}$} & \multicolumn{2}{|c|}{$\begin{array}{l}\text { Roadway } \\
\text { Max:Min } \\
\text { Uniformity }\end{array}$} & \multicolumn{2}{|c|}{$\begin{array}{c}\text { Veiling } \\
\text { Luminance } \\
\text { Ratio }\end{array}$} \\
\hline & & Target & Predict. & Target & Predict. & Target & Predict. & Target & Predict. \\
\hline \multirow{4}{*}{ Day } & Threshold & 140 to 170 & 134 & \multirow{4}{*}{$\leq 2.0$} & 1.3 & \multirow{4}{*}{$\leq 3.5$} & 1.5 & \multirow[b]{2}{*}{$\mathrm{n} / \mathrm{a}$} & - \\
\hline & $\begin{array}{c}\text { Transition } \\
\left(1^{\text {st }} \text { step }\right)\end{array}$ & ratio $\leq 2.5$ & 4.1 ratio & & 1.4 & & 2.5 & & - \\
\hline & \multirow{2}{*}{$\begin{array}{c}\text { Interior } \\
\text { (2nd step) }\end{array}$} & $\geq 3$ & 6.3 & & \multirow{2}{*}{1.1} & & \multirow{2}{*}{2.1} & \multirow{2}{*}{$\leq 0.3$} & \multirow{2}{*}{0.11} \\
\hline & & ratio $\leq 2.5$ & 5.3 ratio & & & & & & \\
\hline \multirow{3}{*}{ Night } & Threshold & \multirow{3}{*}{$\geq 2.5$} & 2.7 & \multirow{3}{*}{$\leq 2.0$} & 2.0 & \multirow{3}{*}{$\leq 3.5$} & 3.0 & \multirow{2}{*}{$\mathrm{n} / \mathrm{a}$} & - \\
\hline & Transition & & 3.2 & & 1.2 & & 1.5 & & - \\
\hline & Interior & & 3.0 & & 1.3 & & 1.7 & $\leq 0.3$ & 0.17 \\
\hline
\end{tabular}

The current level of illumination in the threshold zone appears to fall just short of current IES recommendations for daytime operation. However, these calculations conservatively assume no daylight contribution, so field measurements will likely yield somewhat higher levels than predicted. IES indicates daylight can provide adequate illumination for approximately the first 23 and the last 49 feet of the tunnel. Nighttime threshold uniformity appears slightly sub-standard but is probably adequate.

The luminance gradients from threshold zone to transition zone and from transition zone to interior zone are both considered excessive. The transition zone length is clearly inadequate by current IES standards, as indicated in Table 4.3. The transition zone should be divided into a minimum of four "steps" to allow drivers to gradually adapt to interior zone levels, and a fifth step should be added to the threshold zone. Table 4 summarizes existing and recommended zone lengths.

Table 4.3. Zone lengths and transitional luminance "steps"

\begin{tabular}{|c|c|c|c|c|}
\hline \multirow{2}{*}{ Zone } & \multicolumn{2}{|c|}{ Existing per NPS } & \multicolumn{2}{c|}{ IES minimum ${ }^{9}$} \\
\cline { 2 - 5 } & Length (ft) & \# steps & Length (ft) & \# steps \\
\hline Threshold & 200 & $\mathbf{0}$ & 176 & 1 \\
\hline Transition & $\mathbf{2 5 0}$ & $\mathbf{1}$ & 660 & 4 \\
\hline Interior & 1460 & 1 & $\mathrm{n} / \mathrm{a}$ & 1 \\
\hline
\end{tabular}

Photometric criteria and calculations for bikelanes and non-roadway surfaces are summarized in Table 4.4.

\footnotetext{
${ }^{9}$ See Appendix A for spreadsheet calculations.
} 
Table 4.4. IES recommendations vs. estimated existing HPS illumination for non-vehicular surfaces

\begin{tabular}{|c|c|c|c|c|c|c|c|c|c|}
\hline \multirow[t]{2}{*}{$\begin{array}{c}\text { Operating } \\
\text { Mode }\end{array}$} & \multirow[t]{2}{*}{ Zone } & \multicolumn{2}{|c|}{$\begin{array}{c}\text { Bikeway } \\
\text { Average Horizontal } \\
\text { Illuminance (lux) }\end{array}$} & \multicolumn{2}{|c|}{$\begin{array}{l}\text { Bikeway } \\
\text { Avg:Min } \\
\text { Uniformity }\end{array}$} & \multicolumn{2}{|c|}{$\begin{array}{c}\text { Bikeway } \\
\text { Minimum Vertical } \\
\text { Illuminance (lux) }\end{array}$} & \multicolumn{2}{|c|}{$\begin{array}{l}\text { Roadway / Wall } \\
\text { Luminance Ratio }^{10}\end{array}$} \\
\hline & & Target & Predict. & Target & Predict. & Target & Predict. & Target & Predict. \\
\hline \multirow{3}{*}{$\begin{array}{l}\text { Day } \\
\text { (IES) }\end{array}$} & Threshold & \multirow{3}{*}{$\geq 20.0$} & 1877 & \multirow{3}{*}{$\leq 4.0$} & 1.7 & \multirow{3}{*}{$\geq 10.0$} & 376 & \multirow{3}{*}{$\leq 2.5$} & 1.1 \\
\hline & Transition & & 388 & & 1.6 & & 82 & & 1.0 \\
\hline & Interior & & 86 & & 1.1 & & 33 & & 1.0 \\
\hline \multirow{3}{*}{$\begin{array}{l}\text { Night } \\
\text { (IES) }\end{array}$} & Threshold & \multirow{3}{*}{$\geq 20.0$} & 41 & \multirow{3}{*}{$\leq 4.0$} & 12.1 & \multirow{3}{*}{$\geq 10.0$} & 3.9 & \multirow{3}{*}{$\leq 2.5$} & 1.3 \\
\hline & Transition & & 45 & & 1.3 & & 7.9 & & 1.0 \\
\hline & Interior & & 42 & & 1.4 & & 7.4 & & 1.1 \\
\hline
\end{tabular}

Vertical illuminance in the bikelanes is compromised at night by the increased luminaire spacing that results from the extinguishing of daytime-only luminaires, particularly in the interior zone.

Uniformity of horizontal illuminance in the bikelane is compromised at night by the absence of an energized luminaire at the tunnel entrance, as illustrated in Figure 4.1. Note, however, that uniformity of drivelane luminance does meet IES recommendations.

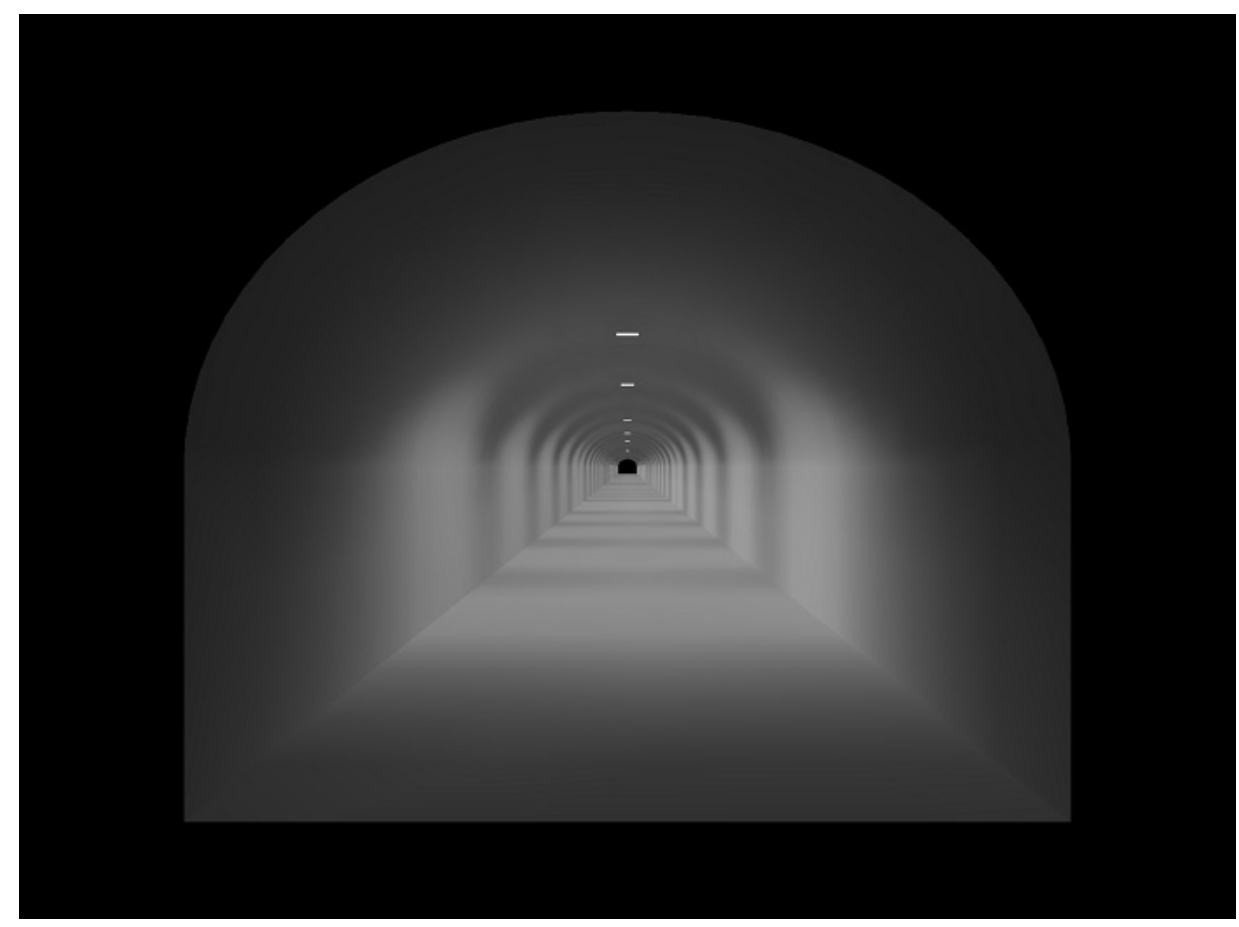

Figure 4.1. Low nighttime light levels at tunnel entrance

\footnotetext{
${ }^{10}$ Wall measurements taken vertically at 3.3 and 6.6 feet above pavement.
} 
Emergency luminaire spacing generally ranges from 74 feet in the threshold and transition zones to 78 feet in the interior zone. However, the emergency luminaires spanning the border between transition and interior zones are spaced 118 feet on center, resulting in measurement points and uniformity ratios which do not comply with National Fire Protection Association (NFPA) requirements, as indicated in Table 4.5. This could be resolved by using luminaires with broader distributions and/or by moving more luminaires to the emergency circuit.

Table 4.5. NFPA requirements vs. estimated existing HPS emergency illumination

\begin{tabular}{|c|c|c|c|c|c|c|c|}
\hline \multirow[t]{2}{*}{$\begin{array}{l}\text { Operating } \\
\text { Mode }\end{array}$} & \multirow[t]{2}{*}{ Zone } & \multicolumn{2}{|c|}{$\begin{array}{c}\text { Bikeway } \\
\text { Average Horizontal } \\
\text { Illuminance (lux) }\end{array}$} & \multicolumn{2}{|c|}{$\begin{array}{c}\text { Bikeway } \\
\text { Minimum Horizontal } \\
\text { Illuminance (lux) }\end{array}$} & \multicolumn{2}{|c|}{$\begin{array}{l}\text { Bikeway } \\
\text { Max:Min } \\
\text { Uniformity }\end{array}$} \\
\hline & & Target & Predict. & Target & Predict. & Target & Predict. \\
\hline Emergency & All & $\geq 10$ & 21 & $\geq 1$ & 0.4 & $\leq 40$ & 132 \\
\hline
\end{tabular}

It is assumed that the emergency circuit is on an adequately sized uninterruptible inverter-type power source, as opposed to a generator, designed to maintain the arc in the event of normal power failure. If the arc were allowed to extinguish, this would result in an unacceptable time delay before restrike, leaving the tunnel in darkness for several minutes.

Note that given the following tunnel characteristics, the simpler IES methods were chosen for determination of required threshold zone luminance (Table vs $\mathrm{L}_{\mathrm{seq}}$ ) and transitioning (Step Down vs Reduction Curve):

- Traffic signals at entrances

- $\quad$ Low speed limit

- Divided traffic

- Existing lighting system serves as baseline

- LED luminaires offer improved color characteristics

New or more demanding tunnels may merit a more extensive analysis by a qualified professional. 


\subsection{LED Alternatives}

Many LED products are available on the market, but few feature performance approaching the challenging requirements of this project. Following is a summary of traits sought as a first-pass filter during the product search:

- Mounts directly to ceiling (preferably not via an "elbow" bracket)

- Less than 12 inches height (for vehicle clearance)

- LED-tailored optical components (as opposed to repurposed HID refractors)

- Photometry and cutsheets available online (not strictly by request)

- IP-65 or better (IP-66 preferred for ease of maintenance)

- Elongated bilaterally symmetric intensity distribution (luminaires are centered across tunnel and the existing fixture spacing is based on an oval-shaped "footprint" of coverage)

- Wide variety of lumen packages offered at same drive current (dimming would add cost)

- Initial output of 20,000 lumens or more (to approach half of 400W HPS)

- Luminaire efficacy comparable or superior to HPS

The search included floodlights, pole-mounted luminaires, and products marketed for application in tunnels, parking structures, canopies, and high-bay or low-bay industrial facilities; a tabulated summary and selected product cutsheets are provided in Appendix D.

As of June 21, 2011, only three of 279 products listed on the Lighting Facts website under fixture type "Outdoor area/roadway fixture" featured initial output exceeding 20,000 lumens. ${ }^{1}$ Two of these products were made by Visionaire Lighting, and the other was made by BetaLED. GATEWAY received confirmation from Visionaire that the high-output ELE-2 and ELE-3 luminaires, which are typically polemounted, could be modified for ceiling-mounting (standard for the smaller ELE-1); however, the approximate $60 \mathrm{~lm} / \mathrm{W}$ efficacy of these products falls short of HPS.

The nearly 30,000 lumen ALX2 from Lithonia Lighting was the highest lumen package found by GATEWAY, but it offers $66 \mathrm{~lm} / \mathrm{W}$ efficacy, is not available in an elliptical intensity distribution, and does not appear to be capable of ceiling-mounting. The $78 \mathrm{~lm} / \mathrm{W}$ efficacy of the over 22,000 lumen ceiling-mounted HBL-192G from Day-Brite Lighting is better, but elliptical "aisle" photometry was not available online.

BetaLED came closest to meeting the above criteria; models used in this analysis are summarized in Table 5.1, and cutsheets are provided in Appendix C. ${ }^{2}$ Although existing locations are utilized where possible, not all luminaires could be simply replaced one-for-one. Also, several new types are introduced to accommodate the added transition zone steps. Note that whereas HPS lamp efficacy increases with increasing nominal wattage, the efficacy of these LED products is not a function of wattage.

\footnotetext{
${ }^{1}$ Average initial output for this dataset was $6373 \mathrm{~lm}$ (SD 3242); average efficacy was $66 \mathrm{~lm} / \mathrm{W}$ (SD 12); average CCT was 5034K (SD 892).

${ }^{2}$ The optic used in this analysis is already available in the LEDway product line, and according to the manufacturer will soon be added to the CAN-EDG product line.
} 
Table 5.1. BetaLED luminaires used in this analysis

\begin{tabular}{|c|c|c|c|c|c|c|c|}
\hline Type & Catalog \# & $\begin{array}{c}\text { Initial } \\
\text { output } \\
(\mathrm{lm})\end{array}$ & $\begin{array}{c}\text { Input } \\
\text { power } \\
(\mathrm{W})\end{array}$ & $\begin{array}{c}\text { Initial } \\
\text { efficacy } \\
(\mathrm{lm} / \mathrm{W})\end{array}$ & Location & Operation & Voltage \\
\hline L4D0 & $\begin{array}{c}\text { CAN-EDG-1S-DM- } \\
\text { 16-D-UH-525-60K }\end{array}$ & 24,820 & 265 & 94 & $\begin{array}{c}\text { Threshold } \\
\text { start }\end{array}$ & $\begin{array}{c}\text { Daytime } \\
\text { only }\end{array}$ & $480 \mathrm{~V}$ \\
\hline L4D1 & $\begin{array}{c}\text { CAN-EDG-1S-DM- } \\
\text { 12-D-UH-525-60K }\end{array}$ & 18,700 & 204 & 92 & $\begin{array}{c}\text { Threshold } \\
\text { step }\end{array}$ & $\begin{array}{c}\text { Daytime } \\
\text { only }\end{array}$ & $480 \mathrm{~V}$ \\
\hline L2D0 & $\begin{array}{c}\text { CAN-EDG-1S-DM- } \\
\text { 14-D-UH-525-60K }\end{array}$ & 21,718 & 233 & 93 & $\begin{array}{c}\text { Transition } \\
\text { start }\end{array}$ & $\begin{array}{c}\text { Daytime } \\
\text { only }\end{array}$ & $480 \mathrm{~V}$ \\
\hline L2D1 & $\begin{array}{c}\text { CAN-EDG-1S-DM- } \\
\text { 14-D-UH-525-60K }\end{array}$ & 21,718 & 233 & 93 & $\begin{array}{c}\text { Transition } \\
\text { step 1 }\end{array}$ & $\begin{array}{c}\text { Daytime } \\
\text { only }\end{array}$ & $480 \mathrm{~V}$ \\
\hline L2D2 & $\begin{array}{c}\text { CAN-EDG-1S-DM- } \\
\text { 16-D-UH-525-60K }\end{array}$ & 24,820 & 265 & 94 & $\begin{array}{c}\text { Transition } \\
\text { step 2 }\end{array}$ & $\begin{array}{c}\text { Daytime } \\
\text { only }\end{array}$ & $480 \mathrm{~V}$ \\
\hline L2D3 & $\begin{array}{c}\text { CAN-EDG-1S-DM- } \\
\text { 08-D-UH-525-60K }\end{array}$ & 12,498 & 133 & 94 & $\begin{array}{c}\text { Transition } \\
\text { step 3 }\end{array}$ & $\begin{array}{c}\text { Daytime } \\
\text { only }\end{array}$ & $480 \mathrm{~V}$ \\
\hline L1C & $\begin{array}{c}\text { CAN-EDG-1S-DM- } \\
\text { 06-D-UH-525-60K }\end{array}$ & 9,374 & 102 & 92 & All zones & Continuous & $480 \mathrm{~V}$ \\
\hline L1E & $\begin{array}{c}\text { CAN-EDG-1S-DM- } \\
\text { 06-D-UL-525-60K }\end{array}$ & 9,374 & 102 & 92 & All zones & $\begin{array}{c}\text { Continuous } \\
\text { and } \\
\text { Emergency }\end{array}$ & $277 \mathrm{~V}$ \\
\hline
\end{tabular}

A correlated color temperature (CCT) of $6000 \mathrm{~K}$ was selected for optimal efficacy; this is offset by the conservatively assumed lumen maintenance or "lamp" lumen depreciation (LLD) of 70\%. Upon release of the forthcoming IES TM-21-11, LED luminaires may be evaluated by one of the following two methodologies:

- Assume the same percentage lumen maintenance for all products, and credit longer-lived products during economic analysis, or

- Assume the same service life (in hours) for all products, and calculate appropriate lumen maintenance percentages for each product separately.

The latter approach may allow for the use of a higher LLD value, which would in turn allow for the use of lower-cost products. In either case, IES LM-80 reports and in-situ temperature measurement test data will be needed for more detailed evaluation of useful lifetime claims when TM-21 is released.

The frequency of hose-down cleaning is liberally assumed to be the same for LED as for HPS, i.e., approximately every 16,800 hours. However, note that whereas the "breathing" effect exhibited by HID luminaires can cause dirt accumulation in the optical chamber, many LED luminaires (like those offered by BetaLED) have no such cavity and only collect dirt on the outside of the lens. Luminaire dirt depreciation is thus assumed to be the same for LED as for HPS.

The 400W HPS luminaires provide just enough light, and cannot be replaced one-for-one by the substantially lower-output LED luminaires. The same LED optic (illustrated in Figure 5.1) was used throughout. 


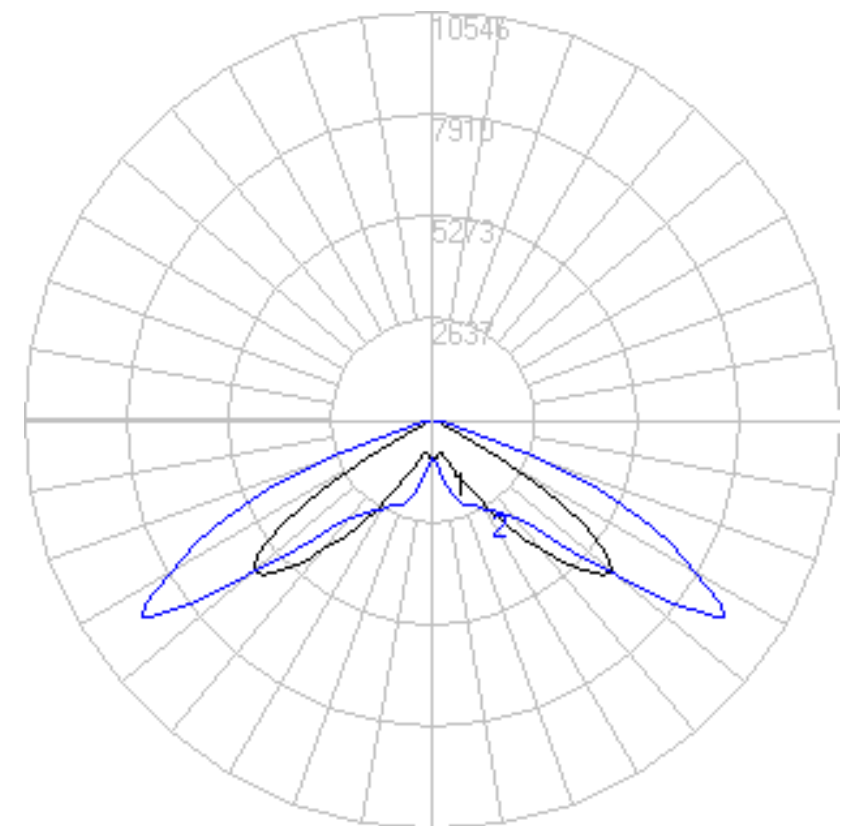

Figure 5.1. Elongated (elliptical) bilaterally symmetric intensity distribution for 191W BetaLED, represented by candela traces for two vertical planes, one at 0-180 degrees horizontal (curve 1 in black) and 90-270 (curve 2 in blue).

GATEWAY analysis indicates more focused beams would neither produce adequate uniformity nor allow for reduced wattage.

Similarly, the use of asymmetric intensity distributions for negative contrast (vertical face of obstacles dark) or positive contrast (vertical face of obstacles luminous) would likely result in increased equipment cost. In theory, an LED luminaire could be designed such that the asymmetric optics reverse direction according to the direction of traffic flow (controlled via the traffic signals); GATEWAY is not aware of any such products. In practice, more LEDs (and more money) would likely be required to achieve this effect.

The 100W HPS luminaires in the interior zone provide too much light by day and just enough light by night. Daytime-only locations in this zone were consequently abandoned, thereby reducing both initial system cost and daytime energy use.

Given the inadequate transition zone, and given the poor bikelane/egress uniformity produced by the nighttime and emergency systems (due to gaps in the layouts), it would be prudent to do some recircuiting if at all possible. The following design assumes that while it is feasible to rewire, it is desirable to either abandon or reuse existing locations, minimizing the creation of new locations - particularly in the interior zone where luminaires are more broadly spaced. Bidding contractors will need to determine whether it would be more cost-effective to simply replace all conduit and junction boxes; if this is the case, luminaire spacing could be revised for improved uniformity and aesthetics.

Transitional lighting is not required for traffic exiting the tunnel; periodic switching of LED luminaires (on at entrance and off at exit) is enabled by the instant-restrike capability of these light sources. 
Proposed revisions to the lighting layout are illustrated in Figure 5.2 below, and are summarized as follows:

- Threshold zone

- Moved two entrance luminaires from daytime circuit to continuous-operation circuit

- Increased number of (lower-output) luminaires as needed

- Switched daytime-only luminaires off approaching tunnel exit

○ Divided into two sub-zones per Table 5.2

- Transition zone

○ Expanded zone length

○ Divided into four sub-zones per Table 5.2

- Increased number of luminaire types and locations as needed

- Moved two luminaires from continuous-operation circuit to emergency circuit

- Switched daytime-only luminaires off approaching tunnel exit

- Interior zone

- Deleted daytime-only luminaire locations

Table 5.2. Revised tunnel zones

\begin{tabular}{|c|c|c|c|}
\hline Zone & Sub-Zone & $\begin{array}{c}\text { Minimum step } \\
\text { duration } \\
\text { (seconds) }\end{array}$ & $\begin{array}{c}\text { Length } \\
\text { (feet) }\end{array}$ \\
\hline Threshold & Start & $\mathrm{n} / \mathrm{a}$ & 120 \\
& Step & 2 & 80 \\
\hline \multirow{5}{*}{ Transition } & Start & 3 & 110 \\
& Step 1 & 4 & 150 \\
& Step 2 & 5 & 190 \\
& Step 3 & 6 & 220 \\
\hline Interior & $\mathrm{n} / \mathrm{a}$ & $\mathrm{n} / \mathrm{a}$ & 620 \\
\hline
\end{tabular}




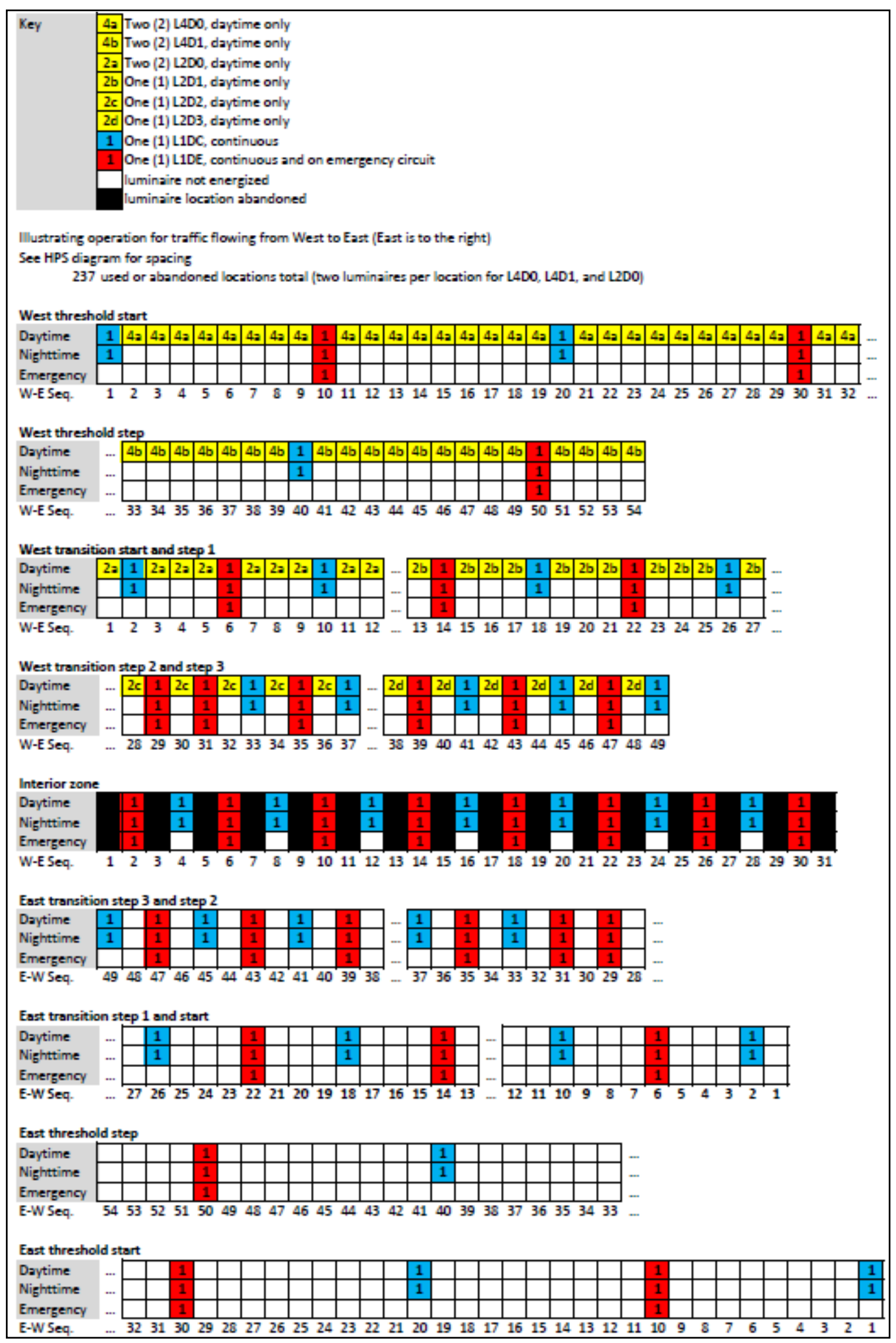

Figure 5.2. Revised layout and circuiting for LED lighting system 
Note that traffic is shown flowing from West to East. In this scenario, daytime transitional lighting is only required on the West end of the tunnel, so daytime-only luminaires (types L4DX and L2DX) in the threshold and transitional zones at the East end of the tunnel are temporarily extinguished.

Also note that luminaire types L4D0, L4D1, and L2D0 are used in pairs - effectively doubling the quantities of existing type H4D and H2D luminaires in these locations. Conduit and/or junction boxes would need to be added accordingly. Luminaires in each L2D0 pair should be located close together (effectively combining to simulate a single luminaire) to prevent issues with flicker effect.

Table 5.3 summarizes the resulting predicted drivelane lighting performance. Daytime luminance in the first part of the threshold zone is slightly below target, but as with the HPS system, this (conservatively) assumes no daylight contribution and is not expected to be problematic.

Table 5.3. IES recommendations vs. estimated LED illumination for the vehicular lane

\begin{tabular}{|c|c|c|c|c|c|c|c|c|c|}
\hline \multirow[t]{2}{*}{$\begin{array}{c}\text { Operating } \\
\text { Mode }\end{array}$} & \multirow[t]{2}{*}{ Zone } & \multicolumn{2}{|c|}{$\begin{array}{l}\text { Average Maintained } \\
\text { Roadway Luminance } \\
\qquad\left(\mathrm{cd} / \mathrm{m}^{2}\right)\end{array}$} & \multicolumn{2}{|c|}{$\begin{array}{l}\text { Roadway } \\
\text { Avg:Min } \\
\text { Uniformity }\end{array}$} & \multicolumn{2}{|c|}{$\begin{array}{l}\text { Roadway } \\
\text { Max:Min } \\
\text { Uniformity }\end{array}$} & \multicolumn{2}{|c|}{$\begin{array}{c}\text { Veiling } \\
\text { Luminance } \\
\text { Ratio }\end{array}$} \\
\hline & & Target & Predict. & Target & Predict. & Target & Predict & Target & Predict. \\
\hline \multirow{8}{*}{ Day } & $\begin{array}{c}\text { Threshold } \\
\text { start }\end{array}$ & $\geq 140$ & 132 & \multirow{8}{*}{$\leq 2.0$} & 1.2 & \multirow{8}{*}{$\leq 3.5$} & 1.5 & \multirow{6}{*}{$\mathrm{n} / \mathrm{a}$} & - \\
\hline & $\begin{array}{c}\text { Threshold } \\
\text { step }\end{array}$ & $\geq 119$ & 120 & & 1.1 & & 1.2 & & - \\
\hline & $\begin{array}{c}\text { Transition } \\
\text { start }^{1}\end{array}$ & ratio $\leq 2.5$ & 2.3 & & 1.3 & & 1.6 & & - \\
\hline & $\begin{array}{c}\text { Transition } \\
\text { step } 1\end{array}$ & ratio $\leq 2.5$ & 2.0 & & 1.2 & & 1.5 & & - \\
\hline & $\begin{array}{c}\text { Transition } \\
\text { step } 2\end{array}$ & ratio $\leq 2.5$ & 2.4 & & 1.3 & & 1.9 & & - \\
\hline & $\begin{array}{c}\text { Transition } \\
\text { step } 3\end{array}$ & ratio $\leq 2.5$ & 1.7 & & 1.1 & & 1.4 & & - \\
\hline & \multirow{2}{*}{ Interior } & $\geq 3$ & 3.1 & & & & & & \\
\hline & & ratio $\leq 2.5$ & 2.3 & & 1.3 & & 5.7 & $=0.5$ & 0.21 \\
\hline \multirow{3}{*}{ Night } & Threshold & \multirow{3}{*}{$\geq 2.5$} & 3.3 & \multirow{3}{*}{$\leq 2.0$} & 1.6 & \multirow{3}{*}{$\leq 3.5$} & 2.6 & \multirow{2}{*}{$\mathrm{n} / \mathrm{a}$} & - \\
\hline & Transition & & 3.1 & & 1.6 & & 2.7 & & - \\
\hline & Interior & & 3.0 & & 1.9 & & 3.2 & $\leq 0.3$ & 0.21 \\
\hline
\end{tabular}

Table 5.4 summarizes the predicted illumination of bikelanes and vertical surfaces. Daytime vertical illuminance in the bikelanes is compromised slightly by the elimination of daytime-only luminaires in the interior zone. Performance would now be consistent across daytime and nighttime operation, and superior to the existing HPS luminaires at night. For greater system cost, but comparable energy use and

\footnotetext{
${ }^{1}$ The ratio for transition start is taken relative to threshold start, not threshold step.
} 
improved vertical illumination, NPS could instead retain all existing locations and use lower-output luminaires.

Table 5.4. IES recommendations vs. estimated LED illumination for non-vehicular surfaces

\begin{tabular}{|c|c|c|c|c|c|c|c|c|c|}
\hline \multirow[t]{2}{*}{$\begin{array}{l}\text { Operating } \\
\text { Mode }\end{array}$} & \multirow[t]{2}{*}{ Zone } & \multicolumn{2}{|c|}{$\begin{array}{c}\text { Bikeway } \\
\text { Average Horizontal } \\
\text { Illuminance (lux) }\end{array}$} & \multicolumn{2}{|c|}{$\begin{array}{l}\text { Bikeway } \\
\text { Avg:Min } \\
\text { Uniformity } \\
\end{array}$} & \multicolumn{2}{|c|}{$\begin{array}{c}\text { Bikeway } \\
\text { Minimum Vertical } \\
\text { Illuminance (lux) }\end{array}$} & \multicolumn{2}{|c|}{$\begin{array}{l}\text { Roadway / Wall } \\
\text { Luminance Ratio }^{1}\end{array}$} \\
\hline & & Target & Predict. & Target & Predict. & Target & Predict. & Target & Predict. \\
\hline \multirow{7}{*}{$\begin{array}{l}\text { Day } \\
\text { (IES) }\end{array}$} & $\begin{array}{c}\text { Threshold } \\
\text { start }\end{array}$ & \multirow{7}{*}{$\geq 20.0$} & 1474 & \multirow{7}{*}{$\leq 4.0$} & 1.5 & \multirow{7}{*}{$\geq 10.0$} & \multirow{7}{*}{9.0} & \multirow{7}{*}{$\leq 2.5$} & 0.7 \\
\hline & $\begin{array}{l}\text { Threshold } \\
\text { step }\end{array}$ & & 1699 & & 1.0 & & & & 0.6 \\
\hline & $\begin{array}{c}\text { Transition } \\
\text { start }\end{array}$ & & 879 & & 1.3 & & & & 0.7 \\
\hline & $\begin{array}{c}\text { Transition } \\
\text { step } 1\end{array}$ & & 415 & & 1.3 & & & & 0.6 \\
\hline & $\begin{array}{l}\text { Transition } \\
\text { step } 2\end{array}$ & & 166 & & 1.3 & & & & 0.7 \\
\hline & $\begin{array}{l}\text { Transition } \\
\text { step } 3\end{array}$ & & 95 & & 1.1 & & & & 0.7 \\
\hline & Interior & & 42 & & 1.6 & & & & 0.7 \\
\hline \multirow{3}{*}{$\begin{array}{l}\text { Night } \\
\text { (IES) }\end{array}$} & Threshold & \multirow{3}{*}{$\geq 20.0$} & \multirow{3}{*}{42} & \multirow{3}{*}{$\leq 4.0$} & \multirow{3}{*}{1.8} & \multirow{3}{*}{$\geq 10.0$} & \multirow{3}{*}{8.7} & \multirow{3}{*}{$\leq 2.5$} & 0.6 \\
\hline & Transition & & & & & & & & 0.6 \\
\hline & Interior & & & & & & & & 0.7 \\
\hline
\end{tabular}

Table 5.5 demonstrates the improved uniformity resulting from the revised emergency lighting.

Table 5.5. NFPA requirements vs. estimated LED emergency illumination

\begin{tabular}{|c|c|c|c|c|c|c|c|}
\hline $\begin{array}{c}\text { Operating } \\
\text { Mode }\end{array}$ & Zone & \multicolumn{2}{|c|}{$\begin{array}{c}\text { Bikeway } \\
\text { Average Horizontal } \\
\text { Illuminance (lux) }\end{array}$} & \multicolumn{2}{c|}{$\begin{array}{c}\text { Bikeway } \\
\text { Minimum Horizontal } \\
\text { Illuminance (lux) }\end{array}$} & \multicolumn{2}{|c|}{$\begin{array}{c}\text { Bikeway } \\
\text { Max:Min } \\
\text { Uniformity }\end{array}$} \\
\cline { 3 - 8 } & & Target & Predict. & Target & Predict. & Target & Predict. \\
\hline Emergency & All & $\geq 10$ & 22 & $\geq 1$ & 4.8 & $\leq 40$ & 12 \\
\hline
\end{tabular}

Energy savings are summarized in Table 5.6. In instances where LED luminaires replace 100W HPS luminaires one-for-one, the increased efficacy allows for $20 \%$ lower wattage. Substantial savings are realized by simply using the traffic signals to toggle daytime-only luminaires (types L4DX and L2DX) on or off based on the direction of traffic flow. Additional savings are attributable to reduced light levels in the interior zone (consistent with IES), but some of these savings are negated by the extended length of the brightly illuminated transition zone. Daytime-only luminaires are assumed to operate 13 hours per day.

\footnotetext{
${ }^{1}$ Wall measurements taken vertically at 3.3 and 6.6 feet above pavement.
} 
Table 5.6. Estimated energy usage by luminaire type

\begin{tabular}{|c|c|c|c|c|c|c|c|c|c|c|}
\hline \multirow{2}{*}{$\begin{array}{l}\text { HPS } \\
\text { type }\end{array}$} & \multirow{2}{*}{$\begin{array}{l}\text { Watts per } \\
\text { location }\end{array}$} & \multirow{2}{*}{$\begin{array}{c}\text { \# of } \\
\text { locations }\end{array}$} & \multicolumn{3}{|c|}{ \# operating } & \multicolumn{3}{|c|}{ Load (kW) } & \multicolumn{2}{|c|}{ Electrical Energy } \\
\hline & & & Day & Night & EM & Day & Night & EM & $\mathrm{kWh} / \mathrm{yr}$ & Annual cost \\
\hline H4D & 464 & 88 & 88 & & & 40.8 & & & 193,881 & $\$ 32,960$ \\
\hline $\mathrm{H} 2 \mathrm{D}$ & 300 & 28 & 28 & & & 8.4 & & & 39,885 & $\$ \quad 6,781$ \\
\hline H1D & 130 & 60 & 60 & & & 7.8 & & & 37,036 & $\$ 6,296$ \\
\hline $\mathrm{H} 1 \mathrm{C}$ & 130 & 31 & 31 & 31 & & 4.0 & 4.0 & & 35,327 & $\$ 6,006$ \\
\hline H1E & 126 & 30 & 30 & 30 & 30 & 3.8 & 3.8 & 3.8 & 33,135 & $\$ 5,633$ \\
\hline \multicolumn{6}{|c|}{ Totals: } & 64.8 & 7.8 & 3.8 & 339,265 & $\$ 57,675$ \\
\hline \multirow{2}{*}{$\begin{array}{l}\text { LED } \\
\text { type }\end{array}$} & \multirow{2}{*}{$\begin{array}{l}\text { Watts per } \\
\text { location }\end{array}$} & \multirow{2}{*}{$\begin{array}{c}\text { \# of } \\
\text { locations }\end{array}$} & \multicolumn{3}{|c|}{ \# operating } & \multicolumn{3}{|c|}{ Load (kW) } & \multicolumn{2}{|c|}{ Electrical Energy } \\
\hline & & & Day & Night & EM & Day & Night & EM & $\mathrm{kWh} / \mathrm{yr}$ & Annual cost \\
\hline L4D0 & 530 & 56 & 28 & & & 14.8 & & & 70,464 & $\$ 11,979$ \\
\hline L4D1 & 408 & 40 & 20 & & & 8.2 & & & 38,746 & $\$ 6,587$ \\
\hline L2D0 & 466 & 18 & 9 & & & 4.2 & & & 19,914 & $\$ 3,385$ \\
\hline L2D1 & 233 & 22 & 11 & & & 2.6 & & & 12,170 & $\$ \quad 2,069$ \\
\hline L2D2 & 265 & 10 & 5 & & & 1.3 & & & 6,291 & $\$ \quad 1,070$ \\
\hline L2D3 & 133 & 12 & 6 & & & 0.8 & & & 3,789 & 644 \\
\hline $\mathrm{L} 1 \mathrm{C}$ & 102 & 31 & 31 & 31 & & 3.2 & 3.2 & & 27,718 & $\$ \quad 4,712$ \\
\hline L1E & 102 & 32 & 32 & 32 & 32 & 3.3 & 3.3 & 3.3 & 28,612 & $\$ \quad 4,864$ \\
\hline \multicolumn{6}{|c|}{ Totals: } & 38.3 & 6.4 & 3.3 & 207,705 & $\$ 35,310$ \\
\hline
\end{tabular}

There appears to be no need to add load to any of the circuits. Assuming the electricity rate is flat, the percent electricity cost savings would equal the estimated 39\% energy savings. Estimated LED product cost is summarized in Table 5.7, based on an informal distributor-net price quote from the manufacturer, and assuming luminaires are not purchased (and marked-up) by the contractor. Excluding installation cost and maintenance savings, and given an average electricity rate of $\$ 0.17 / \mathrm{kWh}$ (per Table 3.2), the simple payback period is estimated at eight years.

Table 5.7. LED luminaire cost

\begin{tabular}{|c|c|rr|r|}
\hline \multirow{2}{*}{ Type } & \multirow{2}{*}{ \# of heads } & \multicolumn{3}{|c|}{ Product cost } \\
\cline { 3 - 5 } & & \multicolumn{2}{|c|}{ Per head } & \multicolumn{2}{|c|}{ By type } \\
\hline L4D0 & 112 & $\$$ & 1,620 & $\$ 181,440$ \\
L4D1 & 80 & $\$$ & 1,300 & $\$ 104,000$ \\
L2D0 & 36 & $\$$ & 1,460 & $\$ 52,560$ \\
L2D1 & 22 & $\$$ & 1,460 & $\$ 32,120$ \\
L2D2 & 10 & $\$$ & 1,620 & $\$ 16,200$ \\
L2D3 & 12 & $\$$ & 980 & $\$ 11,760$ \\
L1C & 31 & $\$$ & 820 & $\$ 25,420$ \\
L1E & 32 & $\$$ & 755 & $\$ 24,160$ \\
\hline \multicolumn{2}{|c|}{ Total: } & $\$ 447,660$ \\
\hline
\end{tabular}




\subsection{Conclusions}

It appears the use of LED luminaires in tunnel lighting applications can be both photometrically viable and economically feasible. Much of the nearly $40 \%$ energy savings ( $132 \mathrm{MWh} / \mathrm{yr}$ ) is attributable to the technology's instant-restrike capability and its high tolerance for frequent switching, which can allow for a $50 \%$ reduction in operating time for daytime-only luminaires in the threshold and transition zones. However, at this time there appears to be only one manufacturer meeting (and a few others approaching) the requirements of this particular project. The shortage of equivalent products may be problematic if three names are required for bidding purposes.

In addition to energy savings and reduced maintenance, the proposed LED lighting system offers the following improvements:

- Duration and gradient of transition brought in line with current IES recommendations

- Bikelane uniformity brought in line with current IES recommendations

- Emergency egress uniformity brought in line with current NFPA requirements.

This analysis relies on a number of assumptions. Following is a summary of items to be physically verified (by others) in the field:

- Tunnel length (opening to opening)

- Surface reflectances

- Airborne particulate density

- Ambient temperature range

- Physical condition of existing junction boxes, conduit, and wiring

- Circuit load capacities

- Luminaire locations and types (optic, ballast, voltage, and circuit)

- Feasibility of interfacing with traffic signals for control of luminaires.

Supplemental to contractor estimates of installation costs for the proposed LED lighting system, the economic analysis would benefit from NPS maintenance cost data for the existing HPS lighting system.

Equipment cost would be reduced and energy savings would be increased if a higher lumen maintenance value were justified per the forthcoming IES TM-21. However, this apparently would not dramatically improve payback. For example, if $85 \%$ lumen maintenance (rather than $70 \%$ ) was estimated this would result in energy savings of approximately $151 \mathrm{MWh} / \mathrm{yr}$, a total cost of $\$ 407,500$ for luminaires, and a simple payback period of seven years (instead of eight). ${ }^{1}$

\footnotetext{
${ }^{1}$ Note that according to the so-called "six times rule" in the draft IES TM-21, a luminaire utilizing light sources backed by 10,000 hours of LM- 80 data cannot be rated for more than 60,000 hours useful lifetime. For a continuously-operated luminaire, this would translate to just under seven years maximum rated useful life. Also, note that lumen maintenance is just one of a number of possible luminaire failure mechanisms.
} 
Alternatively, luminaires could be proactively dimmed to the assumed level of lumen maintenance, effectively harvesting the otherwise wasted energy in the early years of operation, and extending useful life. As the system ages, the degree of dimming would need to be reduced to maintain light levels.

A more elaborate control system could be implemented for increased energy savings, but it is not yet clear whether such a system would prove cost-effective. For example, a system with digitally addressable luminaires and motion sensors could allow for dynamic and automated changes to control zones, thus enabling "chasing" effects whereby luminaires are brought to full power when approached by vehicles and then dimmed (again) to partial output once passed. Wireless controls may offer additional advantages, but application compatibility would need to be verified. However, such advanced control systems may face challenges including sensor coverage (and quantity), sensor degradation, system compatibility, system cost, and possible liability issues. Installation of data-loggers or similar equipment to monitor/reveal the tunnel usage profile would greatly facilitate decision making. 


\subsection{References}

FLH Bridge Inspection and Management Program, 2002. Tunnel Inspection Report. Inspection Type: Routine. "Baker-Barry Tunnel, Bunker Road Through Mountainside, Golden Gate National Recreation Area. Structure No. 8140-003P. Date of Inspection: June 26, 2002.” Office of Federal Lands Highway, Washington, DC.

IES Testing Procedures Committee, Subcommittee on Solid-State Lighting, 2008. IES LM-79-08, "Approved Method: Electrical and Photometric Measurements of Solid-State Lighting Products." Illuminating Engineering Society of North America, New York, NY.

IES Testing Procedures Committee, Subcommittee on Solid-State Lighting, 2008. IES LM-80-08, "IES Approved Method for Measuring Lumen Maintenance of LED Light Sources." Illuminating Engineering Society of North America, New York, NY.

IES Testing Procedures Committee, Subcommittee on Solid-State Lighting, draft in development. IES TM-21-11, "Projecting Long Term Lumen Maintenance of LED Light Sources." Illuminating Engineering Society of North America, New York, NY.

IES Roadway Lighting Committee, Subcommittee on Tunnel Lighting, 2011. ANSI/IES RP-22-11, "American National Standard Practice for Tunnel Lighting." Illuminating Engineering Society of North America, New York, NY.

IESNA Roadway Lighting Committee, Standard Practice Subcommittee, 2000 (reaffirmed 2005). ANSI / IESNA RP-8-00, “American National Standard Practice for Roadway Lighting." Illuminating Engineering Society of North America, New York, NY.

IESNA Roadway Lighting Committee, Subcommittee on Lighting Maintenance \& Light Sources, 2003. IESNA DG-4-03, "Design Guide for Roadway Lighting Maintenance.” Illuminating Engineering Society of North America, New York, NY.

NEMA 2002. "NEMA Standards Publication: A Brief Comparison of NEMA 250 - 'Enclosures for Electrical Equipment (1000 Volts Maximum)' and IEC 60529 - 'Degrees of Protection Provided by Enclosures (IP Code).” National Electrical Manufacturers Association, Rosslyn, VA.

NFPA 2011. NFPA 502, "Standard for Road Tunnels, Bridges, and Other Limited Access Highways." National Fire Protection Association, Quincy, MA.

NPS 1993. Project: PRA GOGA 105(1) Baker-Barry Tunnel, Golden Gate National Recreation Area, Drawing No. 641 / 41985, Pkg. No. 350, Sub. Sheet No. E1-E4, Date: 06/93. National Park Service, Washington, DC. 

Appendix A

\section{Spreadsheet Calculations}





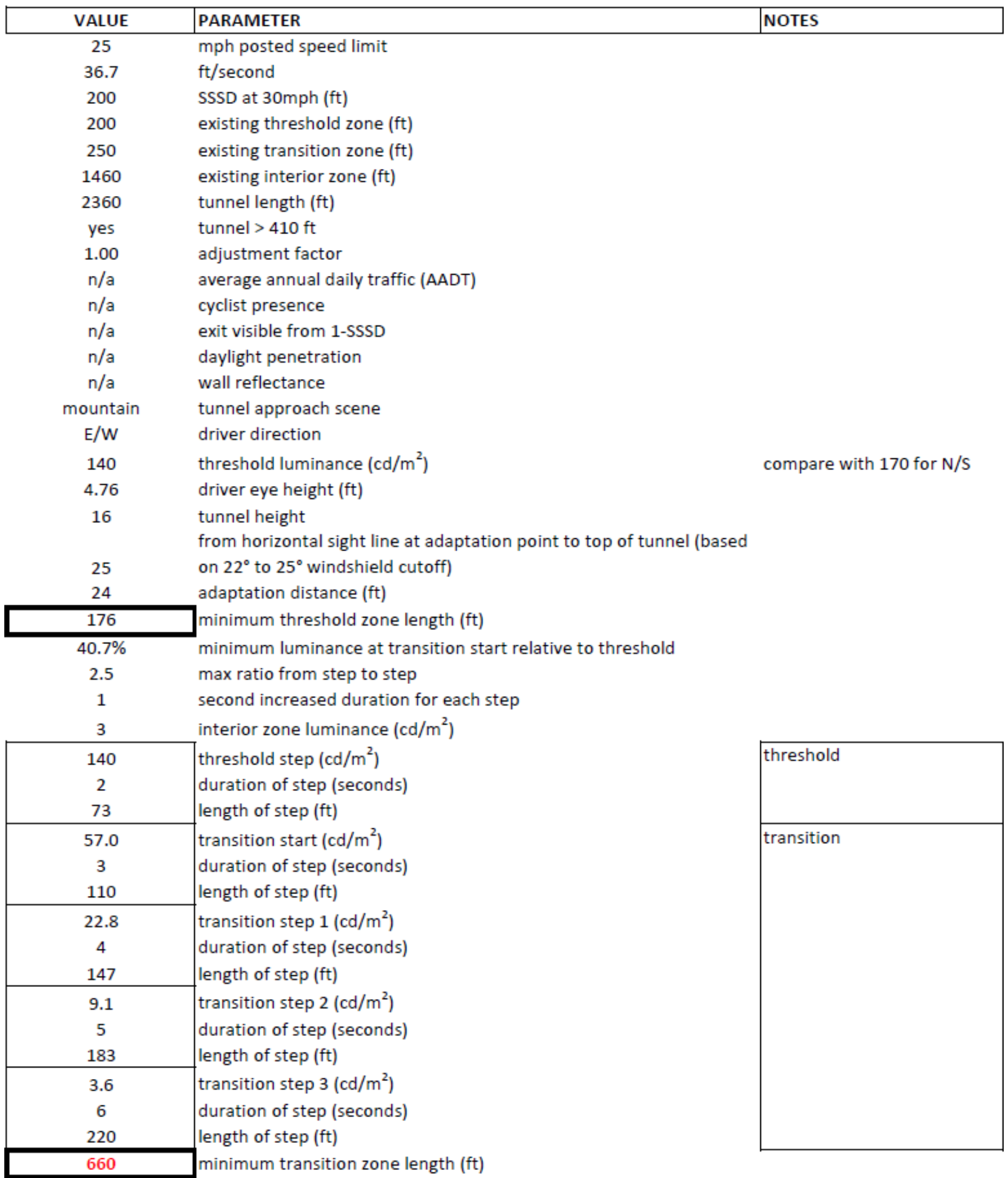





\section{Appendix B}

\section{Luminaire Data - Existing HPS}





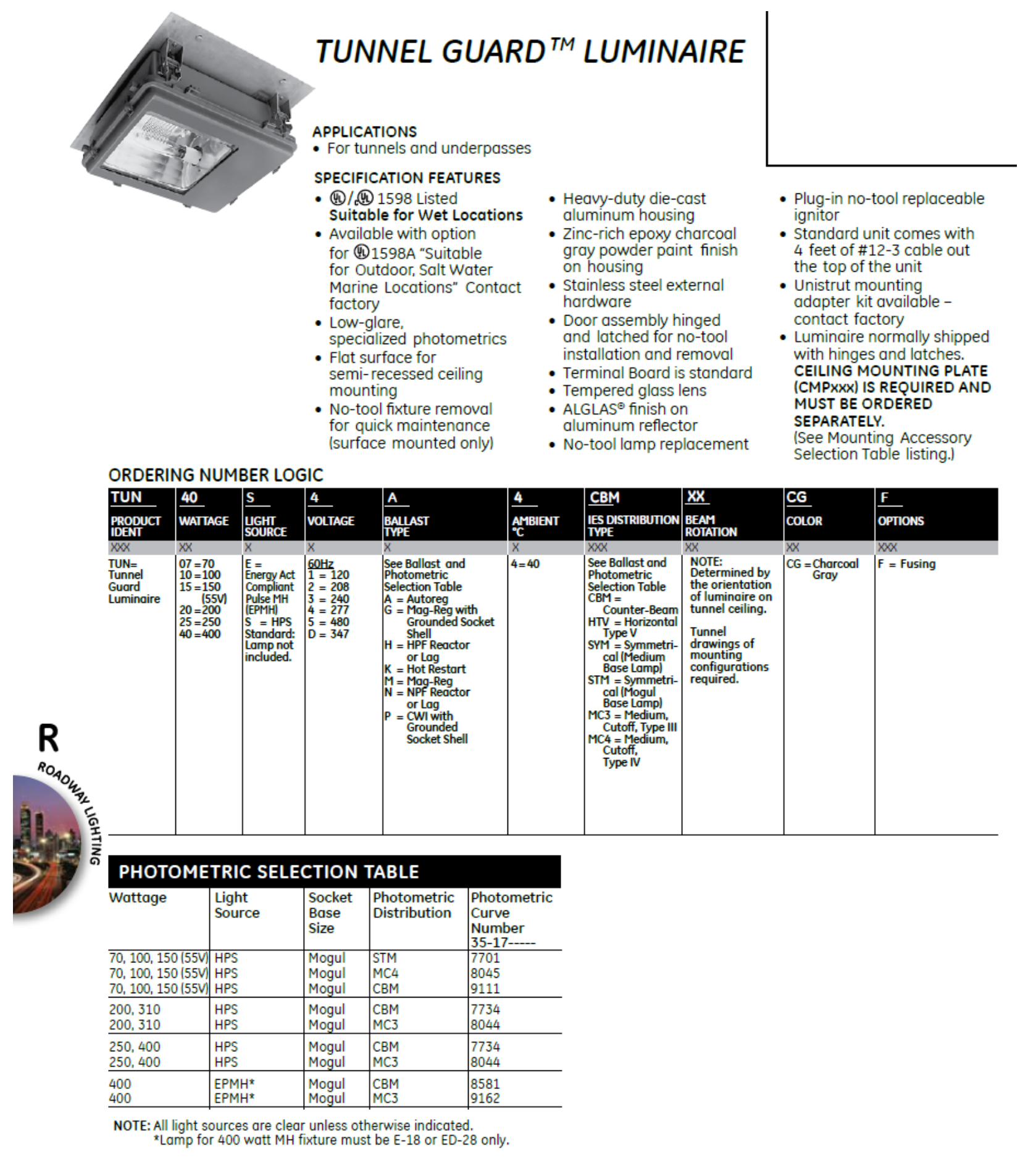

GE Lighting Systems, Inc.

$R-34 / 2008$ 


\section{TUNNEL GUARD TM LUMINAIRE}

FIXTURE DIMENSIONS

CMP001 - Ceiling Mounting Plate (Top Cable Entrance)
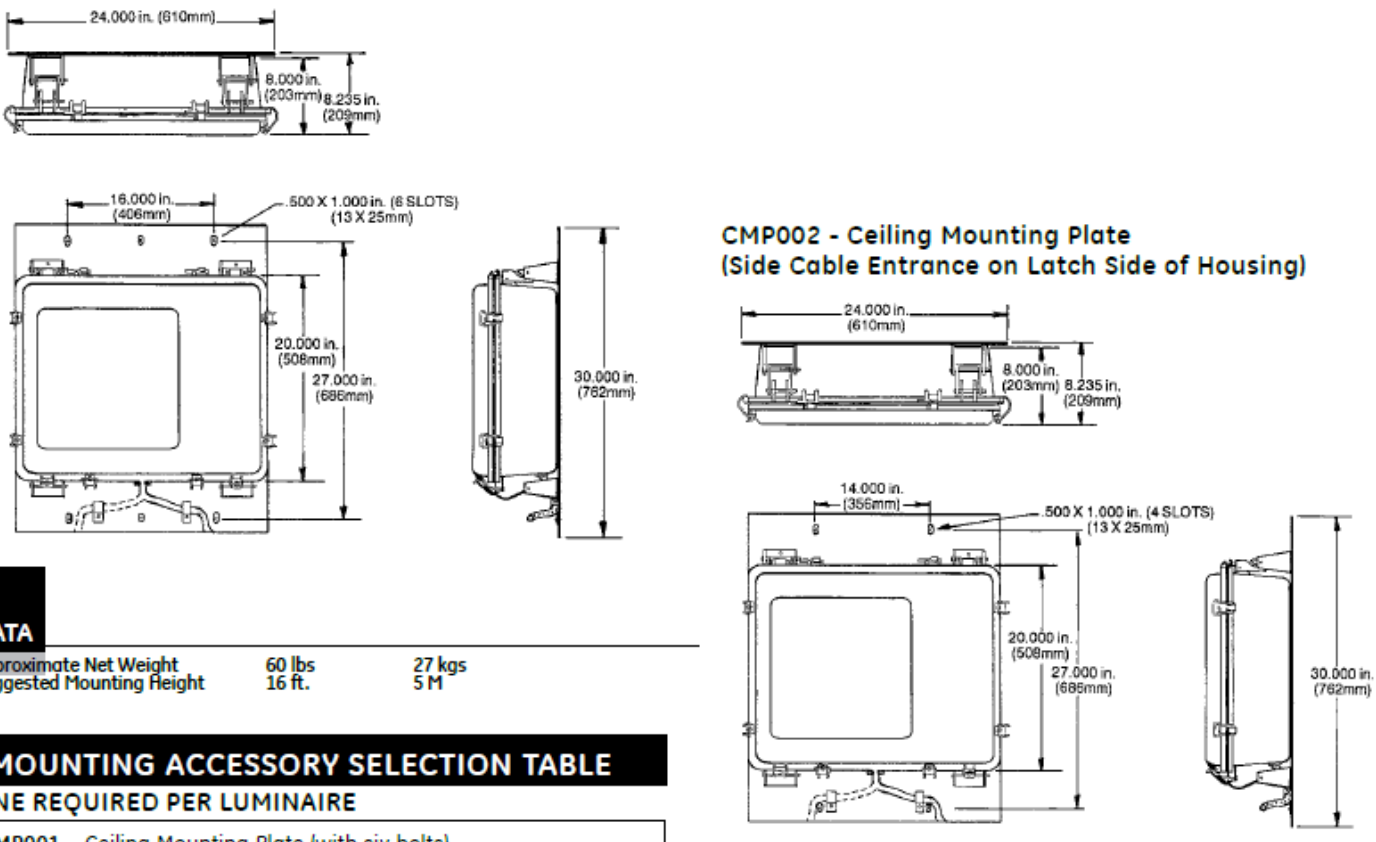

DATA

$\begin{array}{lll}\text { Approximate Net Weight } & 60 \mathrm{lbs} & 27 \mathrm{kgs} \\ \text { Suggested Mounting Height } & 16 \mathrm{ft} . & 5 \mathrm{M}\end{array}$

MOUNTING ACCESSORY SELECTION TABLE

ONE REQUIRED PER LUMINAIRE

CMP001 = Ceiling Mounting Plate (with six bolts)

CMP002 $=$ Ceiling Mounting Plate (with four bolts)

Semi-Recessed Mounting (No UL)

REFERENCES

See Page R-48 for start of Accessories.

See Page R-52 for Explanation of Options and Other Terms Used.
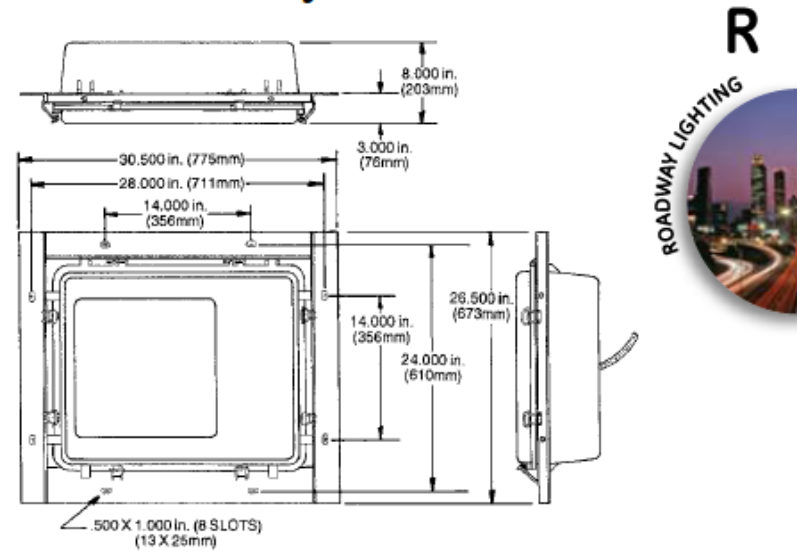

NOTE: $\mathrm{N} / \mathrm{A}=$ Not available

* Not available in $120 \times 347 \mathrm{~V}$

$\star \star 400 \mathrm{~W}$ watt only

GE Lighting Systems, Inc. 
IES ROAD REPORT

PHOTOMETRIC FILENAME : GE177701.IES

DESCRIPTIVE INFORMATION (From Photometric File)

IESNA:LM-63-1995

[TEST] 89022302 PUBLISHED CURVE CREATED

[MANUFAC] GE C\&I, LIGHTING SYSTEMS - EAST FLAT ROCK, NC, USA

[SEARCH] ROADWAY TUN

[LUMINAIRE] TUNNEL GUARD

[DISTRIBUTION] XC2

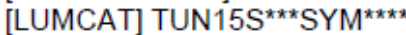

[LAMP] 1; 150W HPS, CLEAR ED23.5, HORZ

[LAMPCAT] GE LU150/55

[OTHER] HSNG: CAST HOUSING CAST DOOR/COVER

[MORE] REFL: SEMI-SPEC HYDROFRM ALUM

[MORE] ENCL: CLEAR SHEET GLASS

[MORE] ACSY:

[MORE] SOCKET POSITION: FIXED

[MORE] COMMENT:

\section{CHARACTERISTICS}

IES Classification

Longitudinal Classification

Cutoff Classification (deprecated)

Lumens Per Lamp

Total Lamp Lumens

Luminaire Lumens

Total Luminaire Efficiency

Downward Total Efficiency

Maximum Candela

Maximum Candela Angle

Maximum Candela ( $<90$ Degrees Vertical)

Maximum Candela Angle ( $<90$ Degrees Vertical)

Maximum Candela At 90 Degrees Vertical

Maximum Candela from 80 to $<90$ Degrees Vertical

Total Luminaire Watts

Ballast Factor
Type II

Very Short

Cutoff

16000 (1 lamp)

16000

12428

$78 \%$

$78 \%$

4968

$35 \mathrm{H} 35 \mathrm{~V}$

4968

$35 \mathrm{H} 35 \mathrm{~V}$

22.4 (0.1\% Lamp Lumens)

163.2 (1.0\% Lamp Lumens)

183

1.00 


\section{POLAR GRAPH}

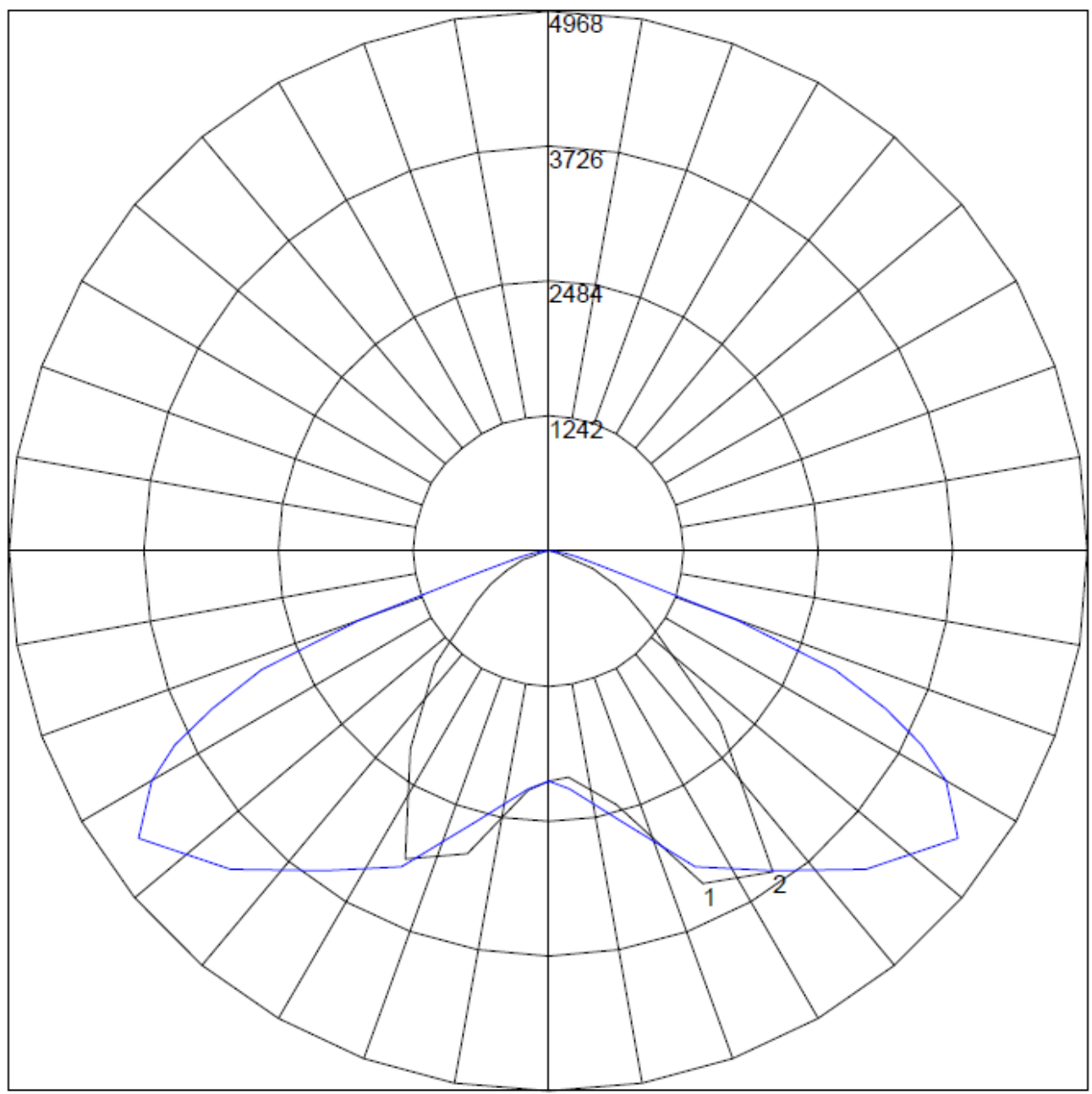

Maximum Candela $=4968$ Located At Horizontal Angle $=35$, Vertical Angle $=35$

\# 1 - Vertical Plane Through Horizontal Angles (0 - 180)

\# 2 - Vertical Plane Through Horizontal Angles (90 - 270) 


\section{W S54}

\section{FHJ-HX-HPFHPS100MT \\ High Pressure Sodium \\ $120 / 208 / 240 / 277$ V $60 \mathrm{~Hz}$}

lighiting

Specification Sheet

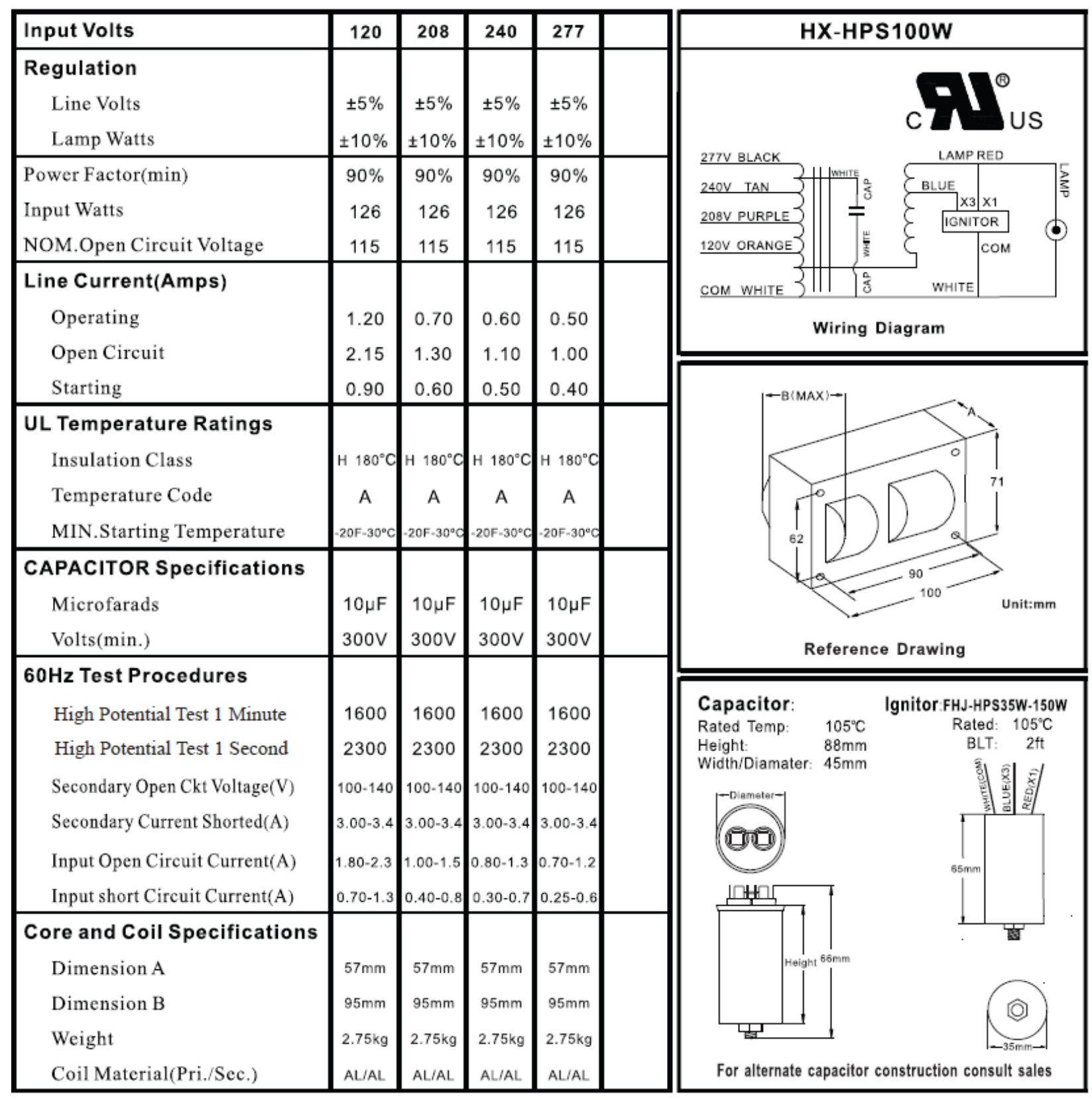

Performance specification information is subject to change without notification.

Xiamen FHJ Lighting Electric CO.,LTD.

No.6 Xiang Hong Road,Torch High-Tech Zone,Xiamen City,Fujian,China

TEL:+86-592- 7760730 FAX:+86-592-7760736

E-mail:sales@fhj-lighting.com

http://www.fhj-lighting.com 



\section{Appendix C}

\section{Luminaire Data - LED Evaluated}





\section{CAN-EDG-5S-DM THE EDGE ${ }^{\text {TM }}$ LED Canopy Light - Type V Short}

Rev. Date: 01/27/10

BetaLED Catalog \#: CAN - EDG - 5S - DM - - C -
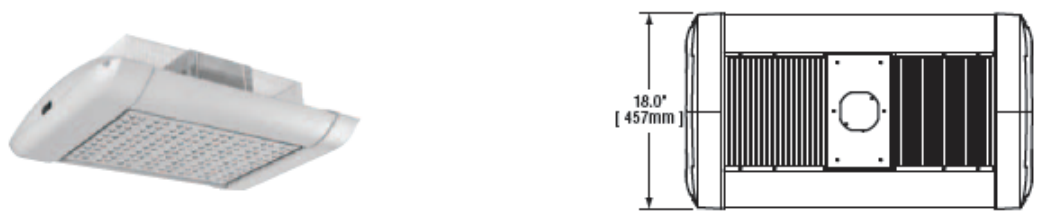

$3.8[97 \mathrm{~mm}] \mathrm{Db}$.

Notes:

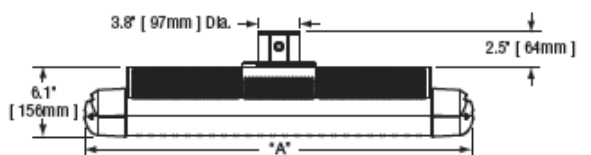

$\downarrow$

\begin{tabular}{|l|l|}
\hline 160 & $23.75^{\circ}$ \\
\hline 180 & $25.75^{\circ}$ \\
\hline 200 & $27.75^{\circ}$ \\
\hline 220 & $29.75^{\circ}$ \\
\hline 240 & $31.75^{\circ}$ \\
\hline
\end{tabular}

Reset

\begin{tabular}{|c|c|c|c|c|c|c|c|}
\hline Product & Family & Optic & Mounting & $\begin{array}{c}\text { \# of LEDs } \\
\left(\begin{array}{l}\times 10 \\
\end{array}\right)\end{array}$ & $\begin{array}{l}\text { LED } \\
\text { Series }\end{array}$ & Voltage & $\begin{array}{c}\text { Color } \\
\text { Options }\end{array}$ \\
\hline CAN & EDG & $5 S^{1}$ & $\mathrm{DM}^{2}$ & $\begin{array}{l}\square 04^{3} \\
\square_{064}^{4} \\
\square_{08} \\
\square_{10} \\
\square_{12} \\
\square_{14} \\
\square_{16} \\
\square_{18} \\
\square^{20} \\
\square^{22} \\
\square 24\end{array}$ & C & $\begin{array}{l}\text { GUL } \\
\text { Universal } \\
120-277 \mathrm{~N} \\
\square \text { UH } \\
\text { Universal } \\
347-480 \mathrm{~V} \\
\square 12 \\
120 \mathrm{~V} \\
\square^{24} \\
240 \mathrm{~V} \\
\square 27 \\
277 \mathrm{~V} \\
\square^{34} \\
347 \mathrm{~V}\end{array}$ & $\begin{array}{c}\square_{\text {Silver }}^{\text {SV }} \\
\square^{\text {BK }} \\
\text { Black } \\
\square^{\text {BZ }} \\
\text { Bronze } \\
\square^{\text {PB }} \\
\text { Platinum } \\
\text { Bronze } \\
\square_{\text {WH }} \\
\text { White }\end{array}$ \\
\hline
\end{tabular}

Factory-Installed Options

Please type addittional options in manually on the Ilines provided above.

口 43K 4300K Color Temperature

$525525 \mathrm{~mA}$ Drive Current ${ }^{6,7}$

DIM 0-10V Dimming ${ }^{\mathrm{a}, \mathrm{e}}$

口 F Fuse ${ }^{10}$

HL Hi/Low (175/350

口 P Photocell ${ }^{13-15}$

TL Two-Level (175/525 w/ integrated sensor control) $)^{12,16,17}$

TL2 Two-Level $(0 / 350 \mathrm{w} / \text { integrated sensor control })^{7,12}$
TL3 Two-Level (0/525 w/ integrated sensor control) $)^{12,16,17}$

\footnotetext{
Footnotes

1. IESNA TYP Y Short distribution 7. Avallable on fluctures with 40-120 Leds

7. Avallable on flxtures with 40-120 LED

8. Control by others

9. Please consult tactory for avallability

. Not avallable with TL, TL2, or TL3 optlons when

UH woltage is selected

4. Usas 100 LED

5. Color 100 LED stze with two blanks in outside postiton

6. Driver operates at $525 \mathrm{~mA}$ Instead of the standard $350 \mathrm{~mA}$

1. Sensor not Included

12. Refer to mult-1evel spec sheet for more Information

13. Must speclly voltage other than UL or UH

14. Not avallable with TL2 or TL3 optlons

15. Not avallable with $H L$ or TL optlons when

UH woltage is selected

16. Avallable on fotures with $40-100$ LEDS

17. Not avallable when UH voltage is selected

\section{LED PERFORMANCE SPECS}

\begin{tabular}{|c|c|c|c|c|c|c|c|c|c|c|c|c|c|c|c|c|}
\hline \multicolumn{17}{|c|}{ LED PERFORMANCE SPECS } \\
\hline \multirow[t]{2}{*}{$\begin{array}{l}\text { \# of } \\
\text { LEDs }\end{array}$} & \multirow[t]{2}{*}{$\begin{array}{c}\text { Initial Delivered } \\
\text { Lumens - Type V } \\
\text { Short } @ 6000 \mathrm{~K}\end{array}$} & B & v & G & \multirow[t]{2}{*}{$\begin{array}{l}\text { Initial Delivered } \\
\text { Lumens - Type V } \\
\text { Short } @ 4300 \mathrm{~K}\end{array}$} & B & U & \multirow[b]{2}{*}{9} & \multirow[t]{2}{*}{$\begin{array}{l}\text { System Watts } \\
120-277 \mathrm{~V}\end{array}$} & \multirow{2}{*}{$\begin{array}{l}\text { Total } \\
\text { Current } \\
@ 120 \mathrm{~V}\end{array}$} & \multirow{2}{*}{$\begin{array}{c}\text { Total } \\
\text { Current } \\
@ 230 \mathrm{~V}\end{array}$} & \multirow[t]{2}{*}{$\begin{array}{l}\text { Total } \\
\text { Current } \\
\text { @ 277V }\end{array}$} & \multirow[t]{2}{*}{$\begin{array}{l}\text { System Watts } \\
347-480 \mathrm{~V}\end{array}$} & \multirow[t]{2}{*}{$\begin{array}{l}\text { Total } \\
\text { Current } \\
\text { @ } 347 \mathrm{~V}\end{array}$} & \multirow[t]{2}{*}{$\begin{array}{l}\text { Total } \\
\text { Current } \\
@ 480 V\end{array}$} & \multirow[t]{2}{*}{$\begin{array}{c}\mathrm{L}_{n,} \text { Hours" } \\
@ 25^{\prime} \mathrm{C} \\
\left(77^{\prime} \mathrm{F}\right)\end{array}$} \\
\hline & & & ting & & & \multirow{2}{*}{\multicolumn{11}{|c|}{$350 \mathrm{~mA}$ (Standard) Fixture Operating at $25^{\circ} \mathrm{C}\left(77^{\circ} \mathrm{F}\right)$}} \\
\hline & & & & & & & & & & & & & & & & \\
\hline $40^{3}$ & $3,833(04)$ & 2 & 0 & 0 & $3,362(04)$ & 2 & 0 & 0 & 49 & 0.41 & 0.23 & 0.20 & 55 & 0.16 & 0.16 & 105,000 \\
\hline $60^{4}$ & $5,750(06)$ & 2 & 0 & 1 & $5,043(06)$ & 2 & 0 & 1 & 71 & 0.60 & 0.32 & 0.28 & 77 & 0.22 & 0.20 & 105,000 \\
\hline 80 & $7,667(08)$ & 3 & 0 & 1 & $6,725(08)$ & 2 & 0 & 1 & 93 & 0.78 & 0.41 & 0.35 & 99 & 0.29 & 0.23 & 105,000 \\
\hline 100 & $9,583(10)$ & 3 & 0 & 1 & $8,406(10)$ & 3 & 0 & 1 & 116 & 0.98 & 0.52 & 0.43 & 123 & 0.35 & 0.28 & 105,000 \\
\hline 120 & 11,500 (12) & 3 & 0 & 1 & $10,087(12)$ & 3 & 0 & 1 & 139 & 1.17 & 0.61 & 0.52 & 146 & 0.42 & 0.33 & 105,000 \\
\hline 140 & $13,417(14)$ & 3 & 1 & 2 & $11,768(14)$ & \begin{tabular}{|l|}
3 \\
\end{tabular} & 0 & 1 & 164 & 1.39 & 0.74 & 0.63 & 172 & 0.50 & 0.37 & 105,000 \\
\hline 160 & $15,333(16)$ & 3 & 1 & 2 & $13,449(16)$ & 3 & 1 & 2 & 186 & 1.58 & 0.83 & 0.71 & 195 & 0.56 & 0.41 & 105,000 \\
\hline 180 & 17,250 (18) & 4 & 1 & 2 & $15,130(18)$ & 3 & 1 & 2 & 211 & 1.77 & 0.93 & 0.79 & 220 & 0.63 & 0.47 & 105,000 \\
\hline 200 & $19,167(20)$ & 4 & 1 & 2 & $16,812(20)$ & 4 & 1 & 2 & 233 & 1.97 & 1.03 & 0.87 & 243 & 0.70 & 0.51 & 105,000 \\
\hline 220 & $21,083(22)$ & 4 & 1 & 2 & $18,493(22)$ & 4 & 1 & 2 & 256 & 2.16 & 1.13 & 0.95 & 267 & 0.77 & 0.56 & 105,000 \\
\hline 240 & $23,000(24)$ & 4 & 1 & 2 & $20,174(24)$ & 4 & \begin{tabular}{|l|l|}
1 \\
\end{tabular} & 2 & 279 & 2.35 & 1.23 & 1.03 & 291 & 0.84 & 0.61 & 105,000 \\
\hline \multicolumn{17}{|c|}{$\begin{array}{ll}525 \mathrm{~mA} \text { Fixture Operating at } 25^{\circ} \mathrm{C}\left(77^{\circ} \mathrm{F}\right) \\
\end{array}$} \\
\hline $40^{3}$ & $4,983(04)$ & 2 & 0 & 1 & $4,371(04)$ & 2 & 0 & 0 & 69 & 0.58 & 0.31 & 0.27 & 75 & 0.22 & 0.19 & 61,000 \\
\hline $60^{4}$ & $7,475(06)$ & 3 & 0 & 1 & $6,556(06)$ & 2 & 0 & 1 & 110 & 0.92 & 0.49 & 0.41 & 116 & 0.33 & 0.27 & 61,000 \\
\hline 80 & $9,967(08)$ & 3 & 0 & 1 & $8,742(08)$ & 3 & 0 & 1 & 138 & 1.16 & 0.62 & 0.54 & 145 & 0.42 & 0.32 & 61,000 \\
\hline 100 & $12,458(10)$ & 3 & 0 & 2 & $10,927(10)$ & 3 & 0 & 1 & 177 & 1.49 & 0.79 & 0.68 & 186 & 0.53 & 0.40 & 61,000 \\
\hline 120 & 14,950 (12) & 3 & 1 & 2 & $13,113(12)$ & 3 & \begin{tabular}{|l|l}
1 \\
\end{tabular} & 2 & 217 & 1.82 & 0.96 & 0.81 & 226 & 0.65 & 0.48 & 61,000 \\
\hline
\end{tabular}

(ㄷ) 2010 BetaLED ${ }^{\oplus}$, a division of Ruud Lighting • 1200 92nd Stre et • Sturtevant, WI 53177 • 800-236-6800 • www.betaLED.com

Made in the U.S.A. of U.S. and imported parts.

Meets Buy American requirements within the ARRA. 


\section{STR-LWY-1S-HT $\quad$ LEDway ${ }^{\circledR}$ Streetlight - Type I Short}

Rev. Date: $4 / 19 / 11$

BetaLED Catalog \#: STR - LWY - 1S - HT - $\quad$ - D - _ _ - _ IP - DIM7 -

Reset

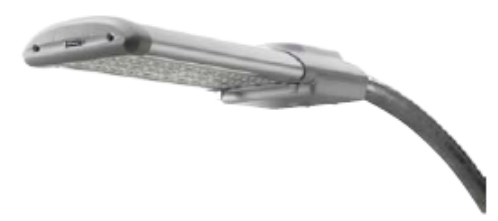

Notes:
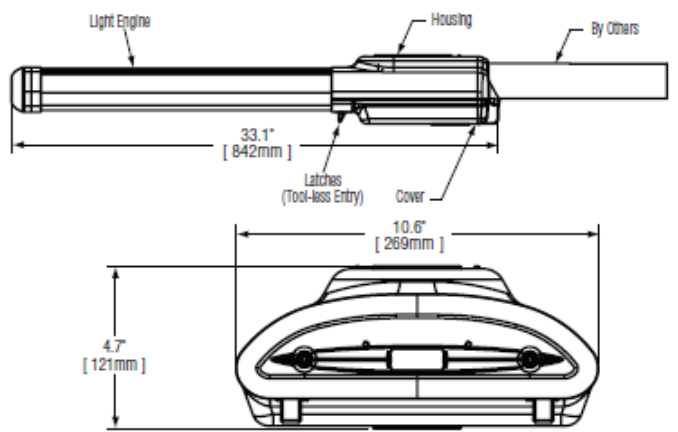

Product Family Optic Mounting \# of LEDs LED Voltage $(x 10)$ Series $\quad$ Options

Drive Factory-Installed Options

$\begin{array}{ccc}\mathbf{0} & \mathbf{0 7} & \mathbf{Q} \text { UL } \\ \mathbf{0 8} & & \text { Universal } \\ \mathbf{0} & & 120-277 \mathrm{~V}\end{array}$

$120-277 \mathrm{~V}$

口 $\mathrm{UH}$

Universal

口 SV

Current

Please type additional optlons in manually on the llnes provided above.

口 700 口 IP IP66 Classification

口 BK

Standar

43K $4300 \mathrm{~K}$ Color Temp

DDIM 0-10V Dimming $5,6,7$

525 F Fuse

口 BZ $\square$ -

Bronze $e^{3} \quad{ }^{350}$ No Quick Disconnect Harness or Leveling Bubble ${ }^{11}$

口 PB $\quad 350 \mathrm{~mA}$ PD Power Door ${ }^{12}$

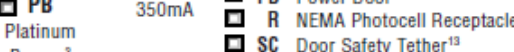

SC Door Safety Tether

TL 2-Level (175/525 w/ integrated sensor control) $)^{10}$

TL1 2-Level (350/700 w/ integrated sensor control) ${ }^{10}$

口 TL2 2-Level $(0 / 350 \mathrm{w} / \text { integrated sensor control })^{10}$

口 TL3 2-Level (0/525 w/ integrated sensor control) $)^{10}$

TL4 2-Level (0/700 w/ integrated sensor control $)^{10}$

口 UTL Utility ${ }^{14}$

Footnotes

1. IESNA Type I Snort distribution

2. Horizontal tenon mount

3. Light engine portion of extrusion is not painted and will remaln

White

natural aluminum regardless or color sabg

ture; minimum $70 \mathrm{CRI}$

5. Control by others

6. Reter to dimming spec sheet for avallabillty and additional

7. Can't exceed the specilied drive current. Consult factory if exceeding

the drive current is necessary.

8. Not avallabie with all multt-level optlons. Reter to mutt-level spec sheet for more avallability and additional

. Wher

Reter to mult level spec sheet for avallability and additional
1. Standard product teatures unless $N$ option is speclited

12. All connectlons between door and fixture are shipped unconnected from the factory; door release spring Included to open do automatically when the latches are relogsec

13. Stainless steel alrcraft cable

14. Includes exterlor wattage label that reflect watts for the specitier drive current selected. The ability to exceged drive current will be dlsabled.

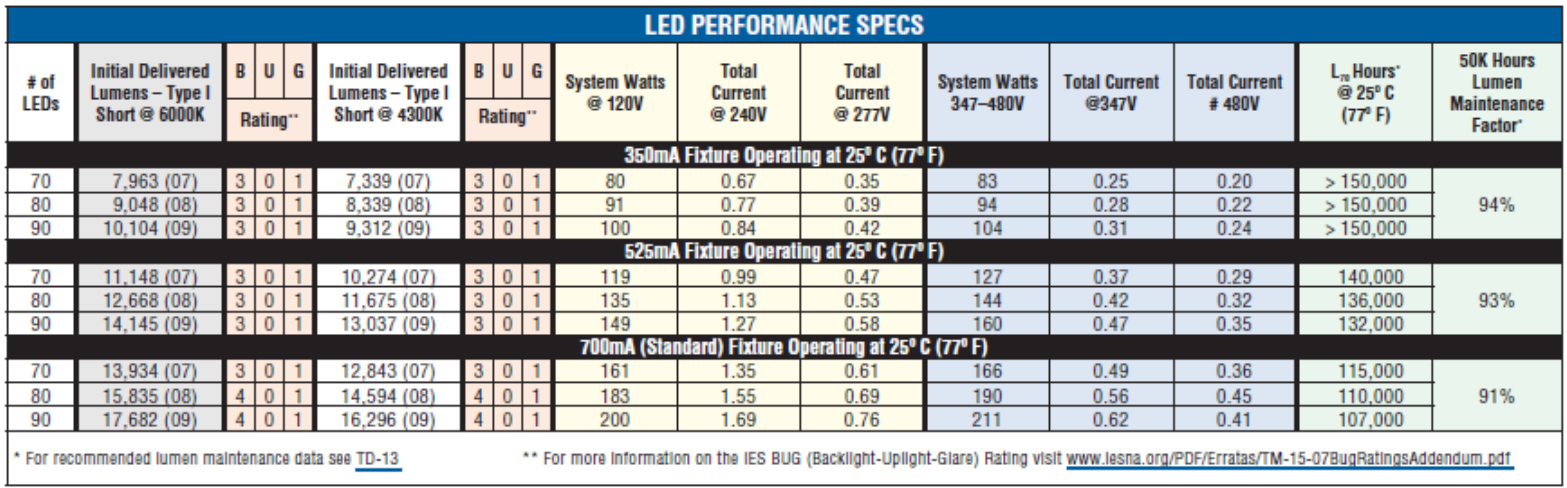

NOTE: All data subject to change without notice.

(C) 2011 BetaLED ${ }^{\oplus}$, a division of Ruud Lighting • 1200 92nd Street • Sturtevant, WI 53177 • 800-236-6800 • www.betaLED.com

Made in the U.S.A. of U.S. and imported parts.

Meets Buy American requirements within the ARRA. 
IES ROAD REPORT

PHOTOMETRIC FILENAME : ARE-EDG-_1S-_-12-D-UL-525-43K.IES

DESCRIPTIVE INFORMATION (From Photometric File)

IESNA:LM-63-2002

[TEST]ITL68091

[TESTLAB]INDEPENDENT TESTING LABORATORIES, INC.

[ISSUEDATE]04/01/11

[MANUFAC]BETALED, A DIVISION OF RUUD LIGHTING

[LUMCAT]ARE-EDG-1S-**-12-D-UL-525-43K or BXAL1T12D-UC7 (525mA)

[LUMINAIRE]120 LED TYPE I SHORT 525mA EDGE AREA

[LAMP]ONE HUNDRED TWENTY WHITE LIGHT EMITTING DIODES (LEDS),

[MORE]VERTICAL BASE-UP POSITION.

[OTHER]TOTAL INPUT WATTS $=190.8$ AT 240.0 VOLTS

[LEDDRIVER]TWO BETALED CE366X03, BETALED CE138X SURGE PROTECTOR

[NOTE]DATA SHOWN IS ABSOLUTE FOR THE SAMPLE PROVIDED AT RATED INPUT

[MORE]VOLTAGE (240VAC, 60Hz) TO THE SURGE PROTECTOR. CLIENT STATES

[MORE]LEDS HAVE BEEN SEASONED FOR A MINIMUM OF 100 HOURS.

[OTHER]TEST PROCEDURE: IESNA LM-79-08

[OTHER]TEST DISTANCE $=25.25$ FEET

[ABSOLUTELUMENS]17295

\section{CHARACTERISTICS}

IES Classification

Longitudinal Classification

Cutoff Classification (deprecated)

Lumens Per Lamp

Total Lamp Lumens

Luminaire Lumens

Total Luminaire Efficiency

Downward Total Efficiency

Upward Waste Light Ratio

Maximum Candela

Maximum Candela Angle

Maximum Candela (<90 Degrees Vertical)

Maximum Candela Angle ( $<90$ Degrees Vertical)

Maximum Candela At 90 Degrees Vertical

Maximum Candela from 80 to $<90$ Degrees Vertical

Total Luminaire Watts

Ballast Factor
Type II

Short

Full Cutoff

N.A. (absolute)

N.A. (absolute)

17295

N.A.

N.A.

0.00

10546

$65 \mathrm{H} 55 \mathrm{~V}$

10546

$65 \mathrm{H} 55 \mathrm{~V}$

0 (0.0\% Luminaire Lumens)

114 (0.7\% Luminaire Lumens)

190.8

1.00

Photometric Toolbox Professional Edition - Copyright 2002-2011 by Lighting Analysts, Inc.

Calculations based on published IES Methods and recommendations, values rounded for display purposes.

Page 1

Results derived from content of manufacturers photometric file. 


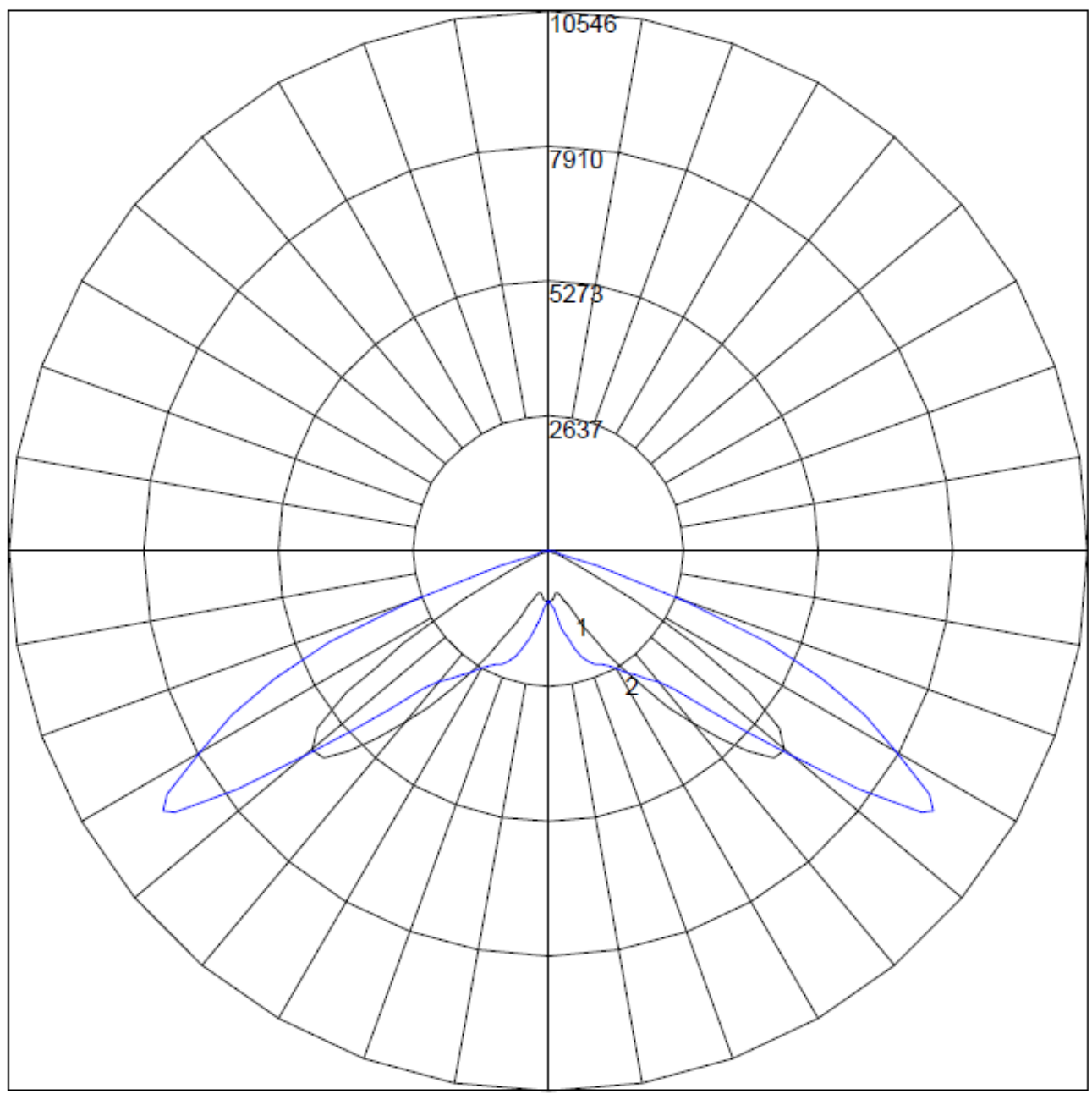

Maximum Candela $=10546$ Located At Horizontal Angle $=65$, Vertical Angle $=55$

\# 1 - Vertical Plane Through Horizontal Angles (0 - 180)

\# 2 - Vertical Plane Through Horizontal Angles (90 - 270) 


\section{Appendix D}

\section{Luminaire Data - Additional LED Products Considered}





\begin{tabular}{|c|c|c|c|}
\hline $\mathrm{mfr} / \mathrm{series}$ & IP rating & $\max 1 \mathrm{~m}$ & notes \\
\hline Affineon CA & 65 & 1750 & \\
\hline Albeo S (sealed) & 56 & . & \\
\hline Beacon Aurora & 66 & 10620 & IP-65 Endura is $7100 \mathrm{~lm}$ \\
\hline Bega 6922LED & 65 & 5370 & \\
\hline BetaLED EDG-CAN & 66 & $24000 \mathrm{x}$ & Gen D source, Type I optic (available in LEDway) \\
\hline Day-Brite HBL & 65 & 22500 & \\
\hline Dialight HB7C4M & 66 & 10430 & \\
\hline Emco ELG & 65 & 7500 & \\
\hline Everlight-Zenaro Caveled & 65 & 3050 & \\
\hline Gardco SFC & 65 & 9571 & DF7 is lower output \\
\hline GELS EGMS & 65 & 8100 & IP-66 asymmetric is $5400 \mathrm{~lm}$ \\
\hline Holophane PLED & 66 & 10418 & $14^{\prime \prime}$ height \\
\hline Hydrel 8200 & 67 & 12900 & 8100 and Rhythm are lower output \\
\hline IntenCity GL50 & 66 & 7000 & \\
\hline Kim PGL7 & 66 & 4200 & offers asymmetric (left/right) optics \\
\hline Lightwild Lusio & 65 & 14000 & \\
\hline Lithonia ALX2 & 67 & 29734 & not for ceiling mounting; IP-65 VAP is $8170 \mathrm{~lm}$ \\
\hline LSGC FLB & 66 & 10280 & \\
\hline LSII XPG3 & 67 & 8300 & IP-67 XHB-series is $12,000 \mathrm{~lm}$ \\
\hline Lumenpulse LumenbeamXL & . & 7271 & Lumenfacade is lower output \\
\hline Lumisave LSFL390 & 65 & 9295 & \\
\hline McGraw CNC/NPL & 66 & 7500 & \\
\hline On-Q & 65 & 10000 & \\
\hline ReLume PSHO & 65 & 11900 & \\
\hline Sportlite GR-52 & . & 5200 & \\
\hline Tersen TLRPG15 & . & 8500 & \\
\hline Traxon WWS-XB-CW & 66 & 2583 & \\
\hline Visionaire ELE-3 & 65 & 24000 & Can be ceiling mounted \\
\hline Wide-Lite VZ & 65 & 7230 & floodlight requires external power supply \\
\hline
\end{tabular}

D. 1 
application

HB-20020

- This luminaire can be used to illuminate

manufacturing, warehousing, gymnasiums, arenas and

many other large indoor spaces with control and

precision.

construction \& features

- Die cast aluminum driver housing.

- Die cast aluminum heat sinks for light engines provide excellent thermal transfer to extend component life.

- Tempered glass lens with molded silicone rubber gasket, seals the optical compartment.

- Polyester powder finish on all die cast parts for excellent impact, corrosion and UV resistance.

- LED light engines and drivers are field replaceable.

- 5 Year Limited Warranty

- Components are RoHS compliant.

electrical

- Listed by ETL to meet UL 1598 standards for damp location and $45^{\circ} \mathrm{C}$ ambient.

- Dimming drivers are standard. Control is 0-10V DC (See wiring notes below)

- Furnished with surge protector.

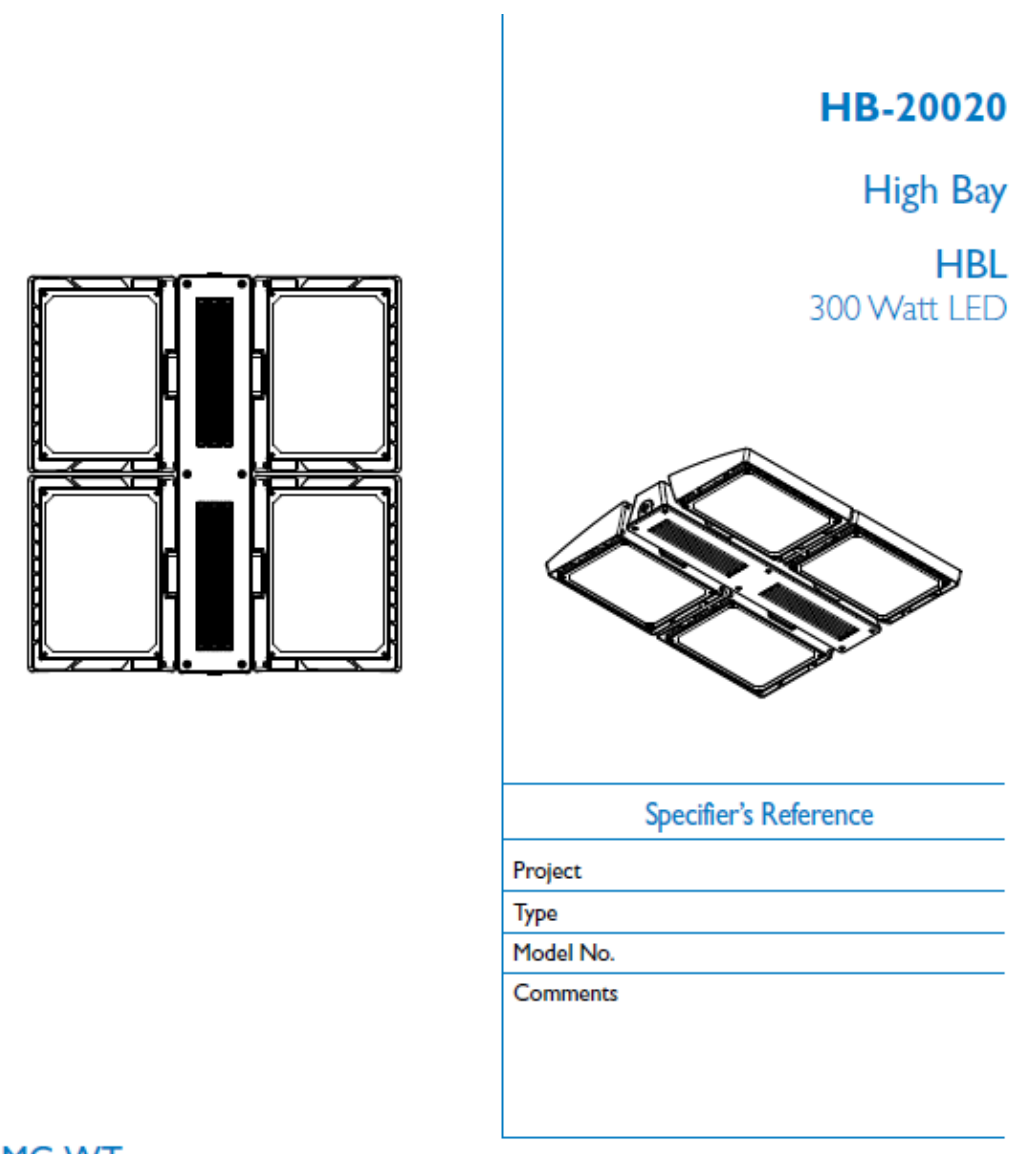

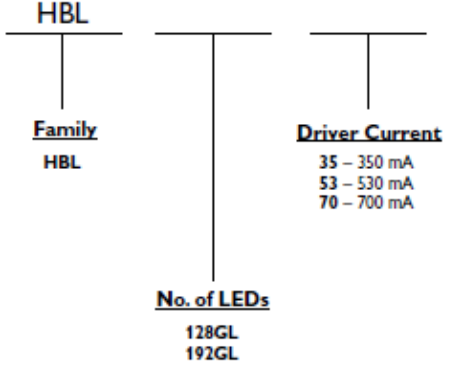
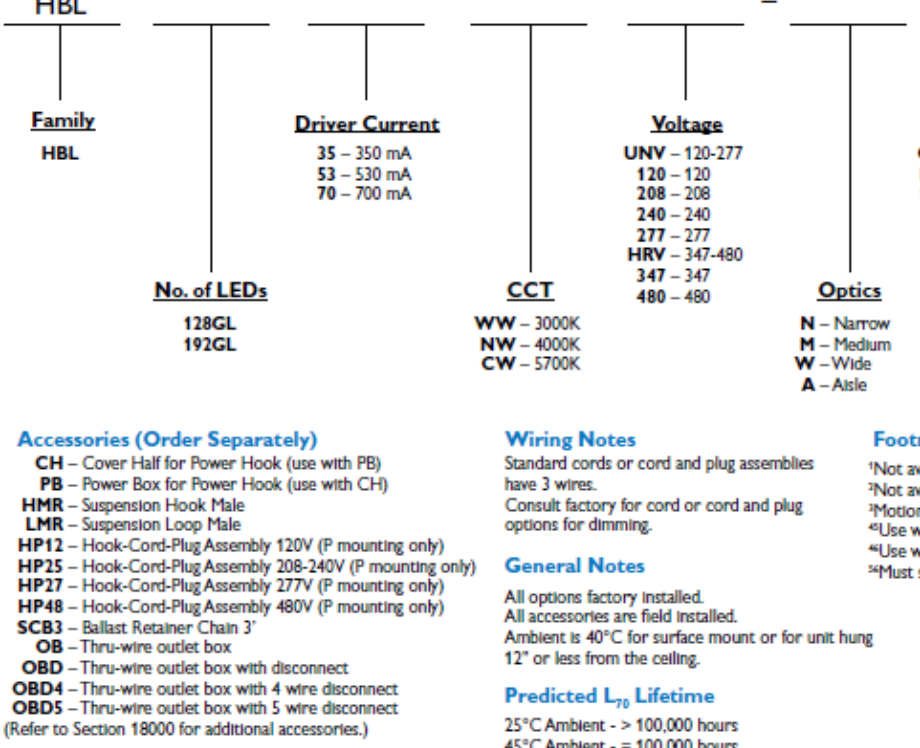

Wiring Notes

Standard cords or cord and plug assemblies

have 3 wires

options for dim for cord or cond and plug
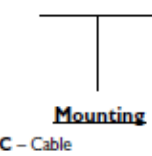

C - Cable
P - Pendant stem or hook

S-Surface Mount

(Requires $\mathrm{OB}$ or $\mathrm{OBD}$. Order Separately)

options for dimming.

'Not avallable with IP65 option

Not avallable with WL option.

Motion detector is onloff only.

«Use with 120,277 and 347 volt

sxMust spectly voltage

All options factory installed.

Ambient is $40^{\circ} \mathrm{C}$ for surface mount or for unit hung

$12^{\prime}$ or less from the celling

Predicted $\mathrm{L}_{70}$ Lifetime

$25^{\circ} \mathrm{C}$ Amblent - > 100, 000 hours

$45^{\circ} \mathrm{C}$ Amblent $-=100,000$ hours

supplied LM-80 data

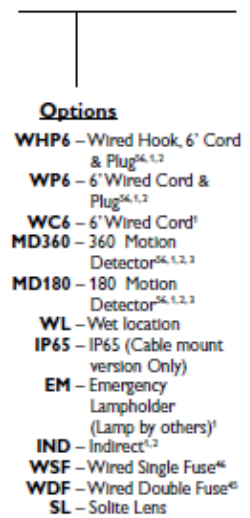

Weight $=36 \mathrm{lbs} .(\max$.

Z-Dark Bronz

WT - White

AL - Silver Aluminum Consult factory for ther colors)

(a) laboratory testing 
HB-20020

\section{dimensions}
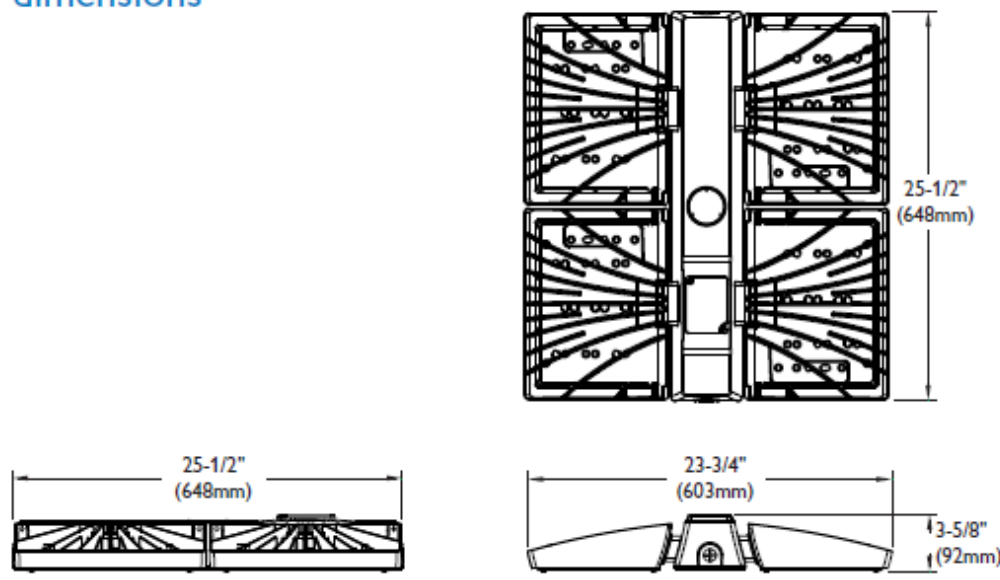

photometry

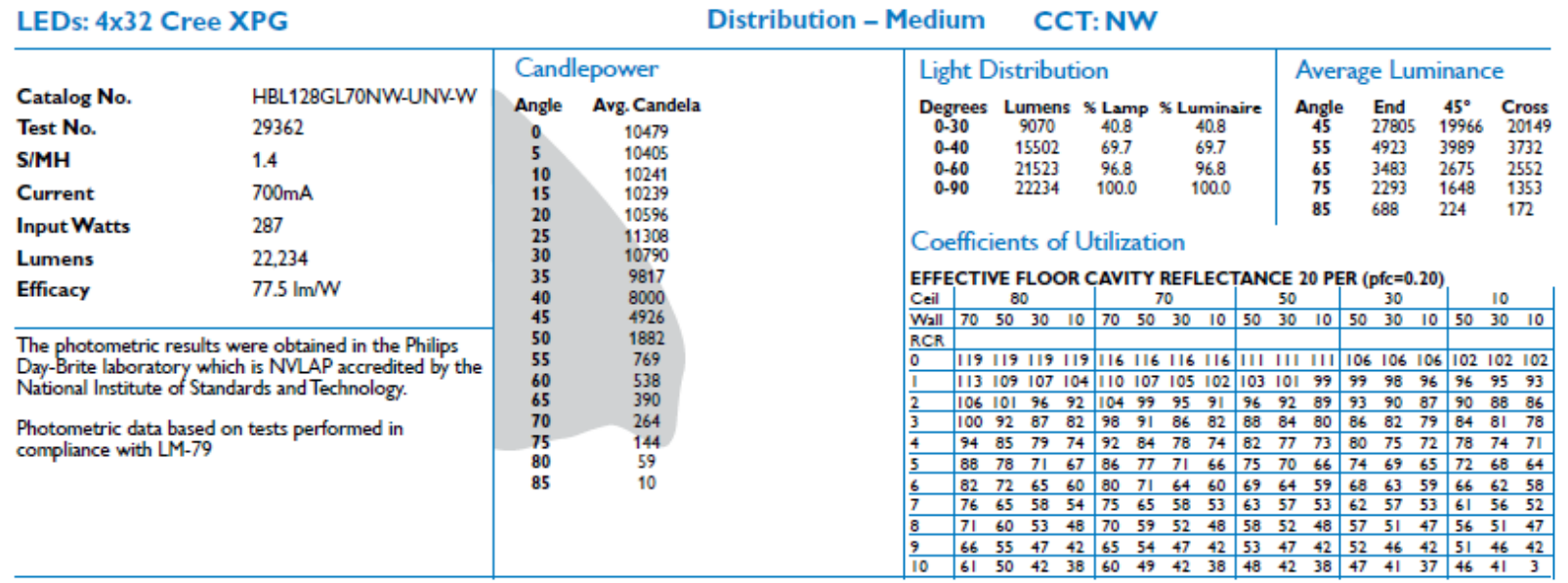

\section{LEDs: $4 \times 32$ Cree XPG}

\begin{tabular}{ll|}
\hline & \\
Catalog No. & HBL128GL70NW-UNV-W \\
Test No. & 29363 \\
S/MH & 2.7 \\
Current & $700 \mathrm{~mA}$ \\
Input Watts & 287 \\
Current & 22,435 \\
Efficacy & $78.2 \mathrm{~lm} / \mathrm{W}$
\end{tabular}

The photometric results were obtained in the Philips Day-Brite laboratory which is NVLAP accredited by the National Institute of Standards and Technology.

Photometric data based on tests performed in compliance with LM-79
Distribution -Wide

CCT:NW

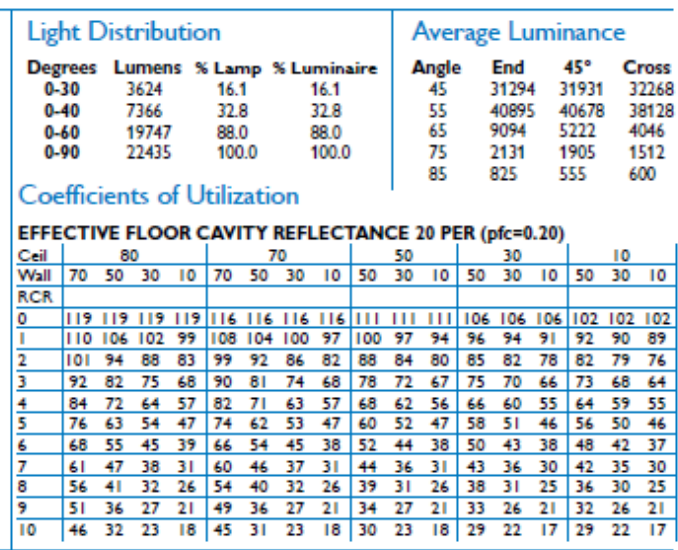

Contact Factory for Additional Configurations.

Specifications are subject to change without notice.
All rights reserved. Revised April 2011.

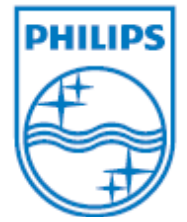

776 South Green Street • Tupelo, MS 38804

p. $800.234 .1890 \cdot$ f. 662.841 .5501

Canadian Division

189 Bullock Drive - Markham, Ontario L3P 1W4

p. $905.294 .9570 \cdot$ f. 905.294 .9811 


\section{$\triangle$ LITHONIA L/EHTINE'}

\section{FEATURES \& SPECIFICATIONS}

INTENDED USE - This softly contoured luminaire seamlessly blends into all forms of architecture. Highly efficient and long-lasting, it is ideal for streets, walkways, parking lots, and surrounding areas.

CONSTRUCTION — Sturdy low-copper aluminum, single-piece die cast housing. Unique flow-through design allows for optimized thermal management through corwective cooling. A metallic screen covers the top of the housing, preventing debris build-up while allowing air-flow and natural deaning of the light engine heat sink. Modular design allows for ease of maintenance and future light engine upgrades. The LED driver and electronics are thermally isol ated from the heat-generating light engine ensuring long life. Housing is completely sealed against moisture and environmental contaminants. Low profile design minimizes wind-loading.

Finish: Exterior parts are protected bya zinc-infused Super DurableTGIC thermoset powder coat finish (available in both textured and non-textured) that provides superior resistance to corrosion and weathering. A tightly controlled multi-stage process ensures a minimum $3 \mathrm{~mm}$ thickness for a finish that can withstand extreme climate changes without cracking orpeeling. Standard Super Durable colors include dark bronze, black, natural aluminum and white.

OPTICS - Individual precision-molded acrylic lenses provide optimal luminaire spacing and improved uniformity. Lenses are indexed to the circuit board to ensure consistent optical alignment on each module and mechanically set in a proprietary material, delivering repeatable photometric performance. Choice of three optimized distributions: Type III, Type IV, and Type V. The optical system controls light above 90 degrees, eliminating wasteful up light.

ELECTRICAL — High-effidency 5100K, 70 CRI LEDs mounted to a metal-core dicuit board and aluminum heat sink, ensuring optimal thermal mana gement and long life (L70 50,000 hrs, 40 ${ }^{\circ} \mathrm{C}$ ambient). Standard and dimming drivers are avallable in $120-277 \mathrm{~V}$ and $347-480 \mathrm{~V} ; 50 / 60 \mathrm{~Hz}$. Drivers have power factor $>90 \%$ and THD $<20 \%$. Thermal isolation results in expected driver life of over 60,000 hours. Integral surge protection in accordance with IEEE/ANSI C62.41.2 Gategory C Low is standard.

INSTALLATION — Integral arm provides easy installation to a pole and ensured alignment and leveling. Rugged, secureconnection built towithstandup to $1.5 \mathrm{G}$ vibration load perANSI C136.31. ALX pole-mounted luminaires utilize the AERIS ${ }^{\mathrm{w}}$ series pole drilling pattern.

LSTINGS - CSA certified to U.S. and Ganadian standardsfor $40^{\circ} \mathrm{C}\left(104^{\circ} \mathrm{F}\right)$ ambient Downward installation only. Light engine is IP67 rated. Luminaire is IP65 rated. US. Patent No. D632830.

WARRANTY — Five-year limited warranty.

Note: Specifications subject to change without notice.

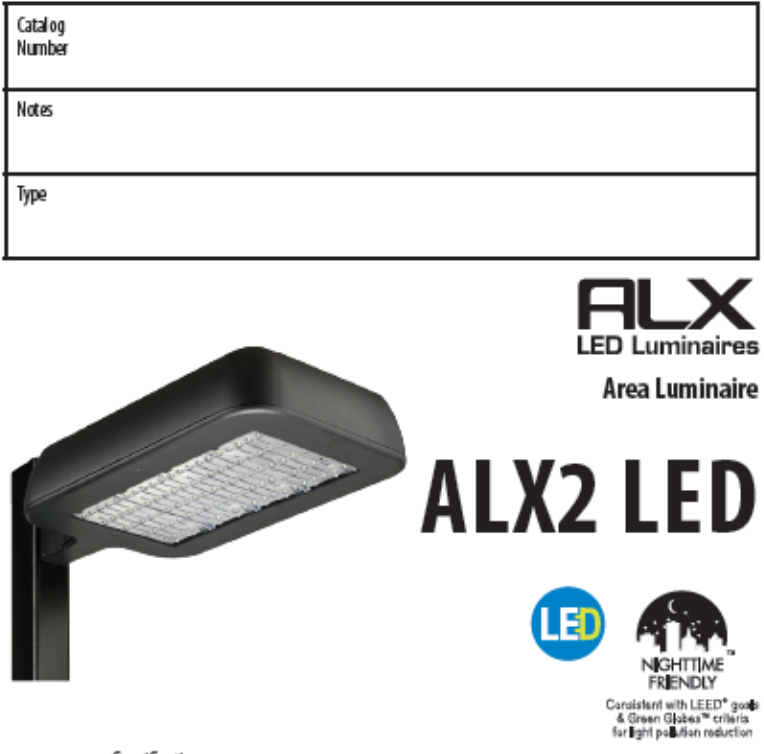

EPA: $1.2 \mathrm{ft}^{2}$

Length: $35-3 / 8(89.7)$

Width: $18-1 / 2(46.9)$

Height: $5-7 / 8(14.9)$

Weight (3 light engines): $74 \mathrm{lbs}(33.6 \mathrm{~kg}$ )

*Weight (4 light engines): $87 \mathrm{lbs}$ (39.4 kg)

"Weight as configured in example below.

All dimensions are Inches (centimeters) unless otherwse noted.

Lead times will vary depending on options selected. Consult with your sales representative.

Example: ALX2 LED 430A350/51K SR5 MVOLT SPA DDBXD

\begin{tabular}{|c|c|c|c|c|c|c|c|c|c|c|c|}
\hline ALX2 LED & & $30 \mathrm{~A} 350 / 51 \mathrm{~K}$ & & & & & & & & & \\
\hline Series & $\begin{array}{l}\text { Number } \\
\text { of light } \\
\text { engines }\end{array}$ & $\begin{array}{l}\text { Performance } \\
\text { package }\end{array}$ & Dist & ution & Voltage & Mour & & Options & & Finish' & \\
\hline ALX2 LED & $\begin{array}{l}3 \\
4\end{array}$ & $30 \mathrm{~A} 350 / 51 \mathrm{~K}$ & & $\begin{array}{l}\text { Type III } \\
\text { Type IV } \\
\text { TypeV }\end{array}$ & $\begin{array}{l}\text { MVoLT' } \\
120 \\
208 \\
240 \\
277 \\
347 \\
480\end{array}$ & $\begin{array}{l}\text { SPA } \\
\text { RPA }\end{array}$ & $\begin{array}{l}\text { Square pole } \\
\text { mounting } \\
\text { Round pole } \\
\text { mountinig }\end{array}$ & $\begin{array}{l}\text { Shipped installed in f } \\
\text { PER } \\
\text { DCR } \\
\text { HS } \\
\text { SF } \\
\text { DF } \\
\text { DMG } \\
\text { WTB } \\
\text { DS } \\
\text { Shipped separately } \\
\text { DSS124N 1.5 TJJE J12 } \\
\text { SCU } \\
\text { VG } \\
\text { BS }\end{array}$ & 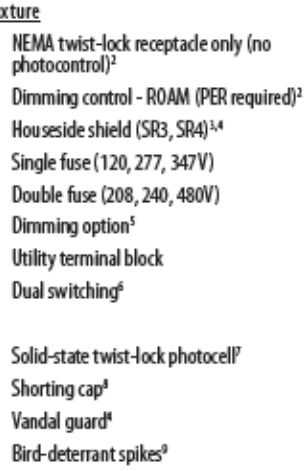 & $\begin{array}{l}\text { DDBXD } \\
\text { DBLXD } \\
\text { DNAXD } \\
\text { DWHXD } \\
\text { DDBTXD } \\
\\
\text { DBLBXD } \\
\text { DNATXD } \\
\text { DWHGXD }\end{array}$ & $\begin{array}{l}\text { Dark bronze } \\
\text { Black } \\
\text { Natural } \\
\text { aluminum } \\
\text { White } \\
\text { Dark bronze } \\
\text { textured } \\
\text { Black textured } \\
\text { Natural } \\
\text { aluminum } \\
\text { textured } \\
\text { White textured }\end{array}$ \\
\hline
\end{tabular}

\begin{tabular}{|c|c|}
\hline \multirow{2}{*}{\multicolumn{2}{|c|}{ 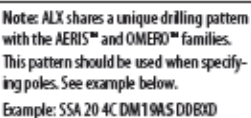 }} \\
\hline & \\
\hline \multicolumn{2}{|c|}{ Aeris Drilling Pattem } \\
\hline DM19AS & 1 at90 degrees \\
\hline DM28AS & 2 at 180 degrees \\
\hline DM29AS & 2 at90 degrees \\
\hline DMB9AS & 3 at90 degrees \\
\hline DMA9AS & 4 at 90 degrees \\
\hline DMB2AS & $\begin{array}{l}3 \text { at } 120 \text { degrees (round } \\
\text { poles only) }\end{array}$ \\
\hline
\end{tabular}

\begin{tabular}{|c|c|c|c|c|c|c|}
\hline \multicolumn{7}{|c|}{$\begin{array}{l}\text { Accessories: Tenon Mounting Slipfitter } \\
\text { Order as separate catalog number. Must be used with polemounting (RPA). }\end{array}$} \\
\hline Tenon 0.D. & One & Two@180 & Iwo@90 & Three@120 & Three@ $@ 90^{\circ}$ & Four $@ 90^{\circ}$ \\
\hline $2-3 / 8^{\prime \prime}$ & AST20-190 & AST $20-200$ & AST20-290 & AST20-320 & AST20-390 & AST20-490 \\
\hline $2-7 / 8^{\circ}$ & AST $25-190$ & AST $25-280$ & AST25-290 & AST25-320 & AST25-390 & AST25-490 \\
\hline $4^{\prime \prime}$ & AST $35-190$ & AST35-200 & AST35-290 & AST $35-320$ & AST35-390 & AST $35-490$ \\
\hline
\end{tabular}

Optional multi-volt driver capable of operation on any line woltage from 120k-277v.

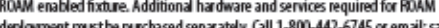
6745 or email: slesid

4 Maye codered as an accessery. lightengine).

Notavailbele with 347 or $420 \%$.

Avaibble with 4 light engines only. Wred with half the LEDs to each branch of the drouit $H / A$ with $P E R, D C R, D M G$ or WTR.

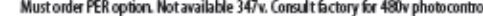
option. Must be ondered as a separate line item from Acuity Brands Controls in multiples of 12

Must be ordered on separate line

For accessory, order as ALDESL Mustspecify frish. 
ALX2 LED Area Lighting

\section{PERFORMANCE DATA}

\begin{tabular}{|c|c|c|c|c|c|c|c|c|c|}
\hline $\begin{array}{c}\text { Number of } \\
\text { light engnes }\end{array}$ & $\begin{array}{c}\text { Performance } \\
\text { padage }\end{array}$ & Distribution & Option & Lumens & B & U & 6 & $\begin{array}{c}\text { System } \\
\text { watts }\end{array}$ & LPW \\
\hline 3 & 30 A350/51K & SR3 & & 21,694 & 3 & 3 & 3 & 336 & 65 \\
\hline 3 & 30 A350/51K & SR4 & & 21,125 & 3 & 3 & 4 & 336 & 63 \\
\hline 3 & 30 A350/51K & SR5 & & 22,380 & 4 & 2 & 2 & 336 & 67 \\
\hline 3 & $30 \mathrm{~A} 350 / 51 \mathrm{~K}$ & SR3 & HS & 11,785 & 1 & 2 & 2 & 336 & 35 \\
\hline 3 & $30 \mathrm{~A} 350 / 51 \mathrm{~K}$ & SR4 & HS & 10,262 & 0 & 3 & 2 & 336 & 31 \\
\hline 4 & $30 \mathrm{~A} 350 / 51 \mathrm{~K}$ & SR3 & & 28,863 & 3 & 3 & 4 & 448 & 64 \\
\hline 4 & $30 \mathrm{~A} 350 / 51 \mathrm{~K}$ & SR4 & & 27,944 & 3 & 3 & 4 & 448 & 62 \\
\hline 4 & $30 \mathrm{~A} 350 / 51 \mathrm{~K}$ & SR5 & & 29,734 & 5 & 2 & 5 & 448 & 66 \\
\hline 4 & $30 \mathrm{~A} 350 / 51 \mathrm{~K}$ & SR3 & HS & 15,530 & 1 & 3 & 3 & 448 & 35 \\
\hline 4 & $30 \mathrm{~A} 350 / 51 \mathrm{~K}$ & SR4 & HS & 14,022 & 1 & 3 & 3 & 448 & 31 \\
\hline
\end{tabular}

\begin{tabular}{|c|c|c|c|c|c|c|c|}
\cline { 3 - 8 } \multicolumn{2}{c|}{} & \multicolumn{7}{|c|}{ Current(A) } \\
\hline Lyght Englines & Power (W) & 120 & 208 & 240 & 277 & 347 & 480 \\
\hline 3 & 336 & 280 & 1.62 & 1.40 & 1.21 & 0.97 & 0.70 \\
\hline 4 & 448 & 3.73 & 2.15 & 1.87 & 1.62 & 1.29 & 0.93 \\
\hline
\end{tabular}

Notes

1 At 277 V.

\section{PHOTOMETRICS}
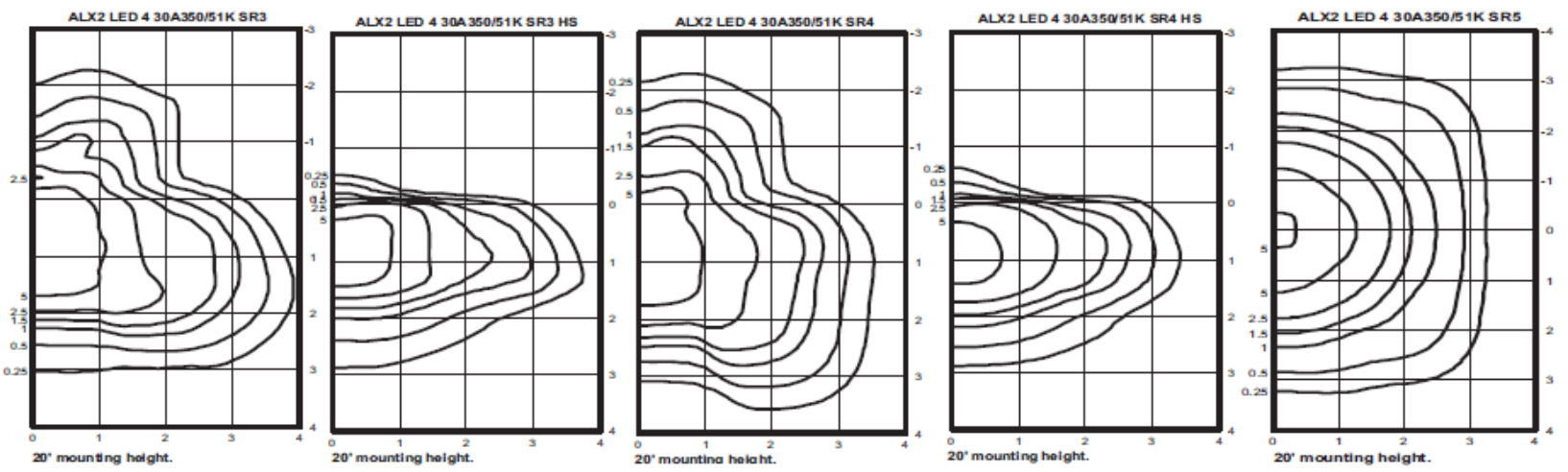

DRILLING TEMPLATE \# 8

IERIS OMEROD) ALX

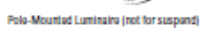

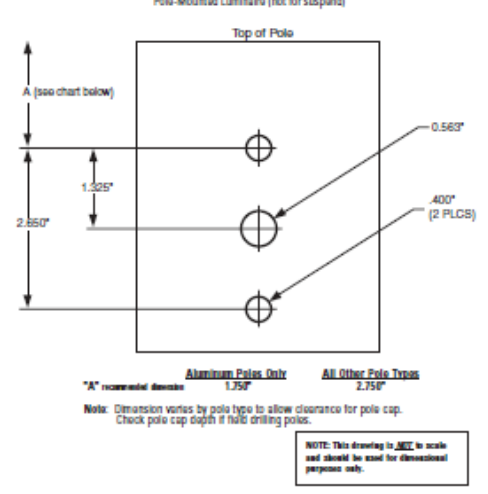

Notes

1 Photometric data for other distributions can be accessed from the Lithonia Lighting web site (www.lithonia.com).

2 For electrical characteristics consult outdoor technical data specification sheets on www.lithonia. com.

3 Various operating factors can cause differences between laboratory and actual field measurements Dimensions and specifications are based on the most current data and are subject to change. Tested to IESNA LM-79-08 standards.

\section{Mounting Height Correction Factor}

(Multiply the fc lenel by the correction factor)

$10 \mathrm{ft.}=4$

$15 \mathrm{ft}=178$

$\begin{array}{ll}30 \mathrm{ft} . & =0.44\end{array}$

$\underline{\text { Existing Mounting Height }}{ }^{2}=$ Correction Factor New Mounting Height ${ }^{2}$

\section{LITHONIA LIEHTINE}

An «AcuityBrands Company

ALX2-LED 


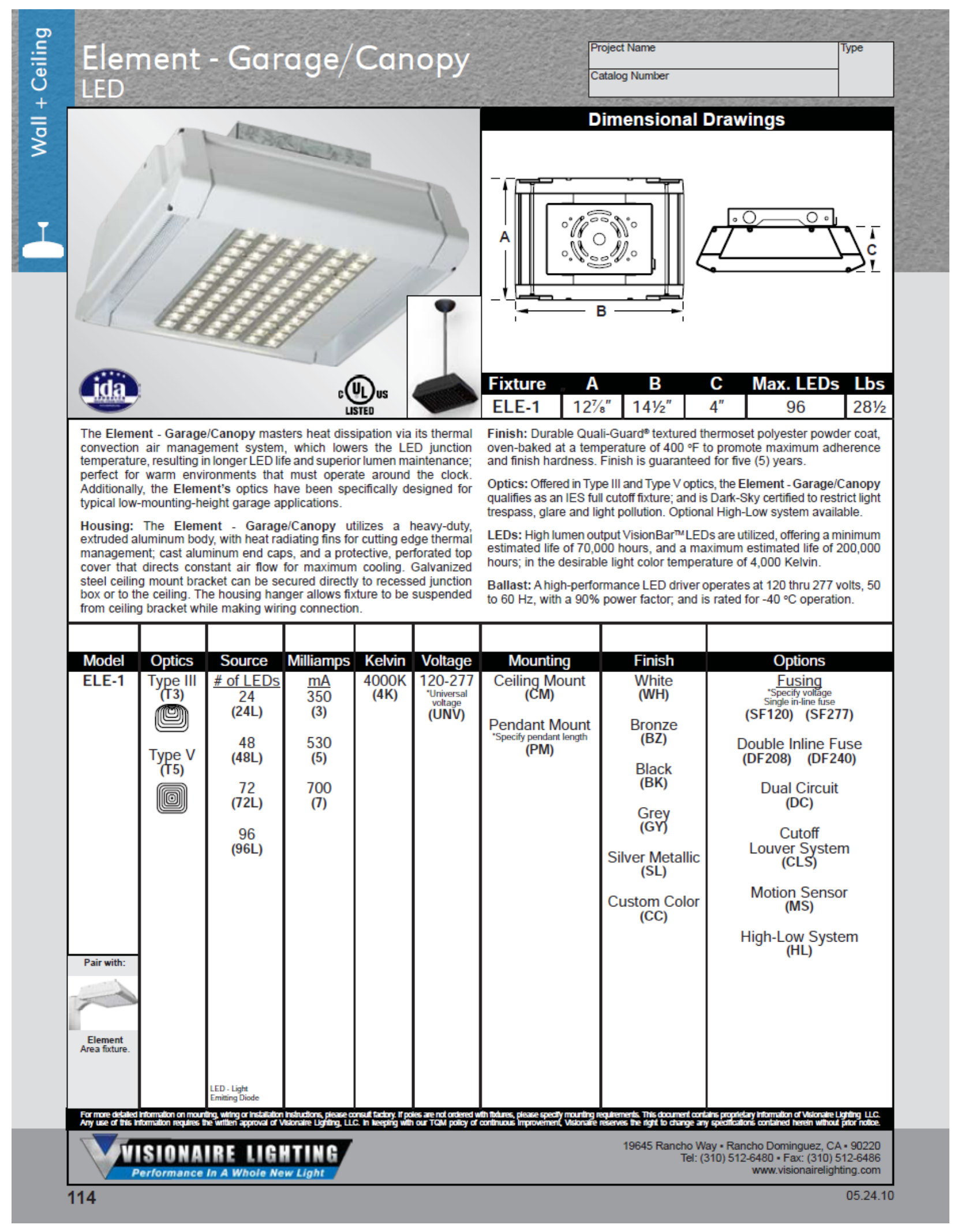




\section{Element - Garage/Canopy}

Housing

- The fixture housing is heavy-duty, extruded aluminum, with heat radiating fins and cast aluminum end caps. Extruded aluminum side covers provide complete protection for the electronic driver. A perforated aluminum top cover protects the heat radiating fins from contaminants and directs constant air flow over them for maximum cooling

\section{Thermal Management}

- The Element - Garage/Canopy provides excellent overall thermal management by maximizing the efficiency of the heat sink in the fixture. This enables the Element - Garage/Canopy to withstand higher ambient temperatures and higher drive currents without degrading LED life. The Element - Garage/Canopy has a low thermal resistance rating. The heat radiating fins and perforated fixture components (see Air Flow Path illustration below) create superior thermal management results.

- The L 70 test determines the point in an LED's life when it reaches 70 percent of its initial output. Element series LEDs have been determined to last 200,000 hours in $40^{\circ} \mathrm{C}$ environments when driven at $350 \mathrm{~mA}$. See chart below for additional test results.

Optical System

- The highest lumen output LEDs available are utilized in the Element series. IES Types III and V distributions are standard. The LED VisionBar ${ }^{\mathrm{TM}}$ light assemblies are field replaceable. Available in nominal wattages from 25 to 200 watts. The optical system qualifies as IES full cutoff; and is Dark-Sky certified to restrict light trespass, glare and light pollution.

\section{Quali-Guard ${ }^{\circ}$ Finish}

- A Quali-Guard ${ }^{\circ}$ thermoset polyester powder coat painted finish is standard, and offered in a variety of colors.

\section{Mounting}

- Galvanized steel ceiling mount bracket can be secured directly to recessed junction box, or to the ceiling. The housing hanger bracket allows fixture to be suspended from ceiling bracket while

\section{LED Data Chart}

\begin{tabular}{|c|c|c|c|c|c|c|}
\hline \multirow{4}{*}{ \# LEDs } & Output mA & $\begin{array}{c}\text { Nominal } \\
\text { Watts }\end{array}$ & $\begin{array}{c}\text { Initial } \\
\text { Lumens } \\
\mathrm{T} 3\end{array}$ & $\begin{array}{c}\text { Initial } \\
\text { Lumens } \\
\text { T5 }\end{array}$ & $\begin{array}{c}\text { System } \\
\text { Watts } \\
120-277\end{array}$ & $\begin{array}{c}\mathrm{L}_{70} \text { Hours } \\
@ 40^{\circ} \mathrm{C}\end{array}$ \\
\hline \multirow{3}{*}{24} & 350 & 25 & 1,771 & 1,946 & 28 & 200,000 \\
\cline { 2 - 7 } & 530 & 35 & 2,439 & 2,680 & 39 & 120,000 \\
\cline { 2 - 7 } & 700 & 50 & 2,962 & 3,255 & 55 & 70,000 \\
\hline \multirow{3}{*}{48} & 350 & 50 & 3,504 & 3,850 & 56 & 200,000 \\
\cline { 2 - 7 } & 530 & 70 & 4,540 & 4,989 & 78 & 120,000 \\
\cline { 2 - 7 } & 700 & 100 & 5,667 & 6,228 & 110 & 70,000 \\
\hline \multirow{3}{*}{72} & 350 & 75 & 5,185 & 5,698 & 84 & 200,000 \\
\cline { 2 - 7 } & 530 & 105 & 6,928 & 7,613 & 117 & 120,000 \\
\cline { 2 - 7 } & 700 & 150 & 8,057 & 8,854 & 165 & 70,000 \\
\hline \multirow{3}{*}{96} & 350 & 100 & 6,916 & 7,600 & 112 & 200,000 \\
\cline { 2 - 7 } & 530 & 140 & 8,911 & 9,792 & 156 & 120,000 \\
\cline { 2 - 7 } & 700 & 200 & 10,072 & 11,068 & 220 & 70,000 \\
\hline
\end{tabular}

\section{Thermal Convection Air Management System}

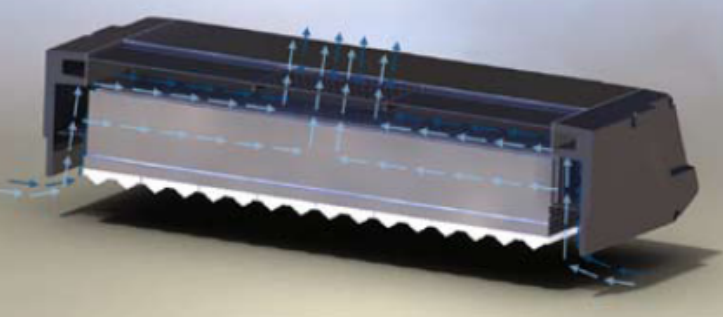

making wiring connection. The housing bracket then attaches to the ceiling bracket via a tool-less latch. A tamper-proof screw can then secure the bracket.

Electrical Assembly

- The Element - Garage/Canopy is supplied with a choice of 350 530 or 700 mA high-performance LED drivers that accept $120 \mathrm{~V}$ thru $277 \mathrm{~V}, 50 \mathrm{~Hz}$ to $60 \mathrm{~Hz}$, input. Power factor of $90 \%$. Rated for $-40^{\circ} \mathrm{C}$ operations.

Warranty

- Five (5) year limited warranty on entire system, including finish For full warranty information, please visit VisionaireLighting.com.

Options

- Dual circuit

- Cutoff louver system

- Motion sensor

- High-low system

Please consult factory for custom options and available upgrades Listings

(10)

listed for wet locations.

- LM79 - LM80

- RoHS Compliant • IP65 • Patent Pending

- Dark-Sky Friendly ${ }^{\star}$, full cutoff certified by the International

Dark-Sky Association

- Powder Coated Tough ${ }^{\mathrm{TM}}$

\section{Ceiling Mount Detail}

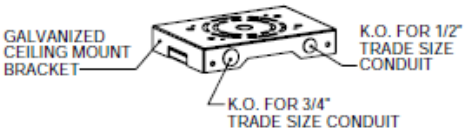

HOUSING HANGER

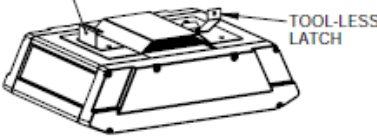

\section{Parking Garage Typical - Open Ceiling}

50 Nominal Watts Driven at $350 \mathrm{~mA}-3,850$ Lumens

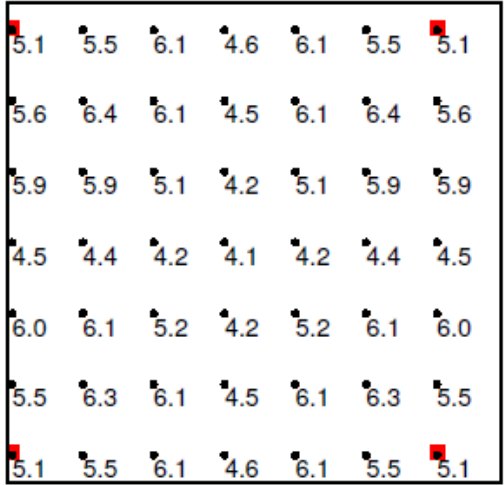

\section{Mounting Height: 10 feet}

30 ' Spacing - Center to Center 


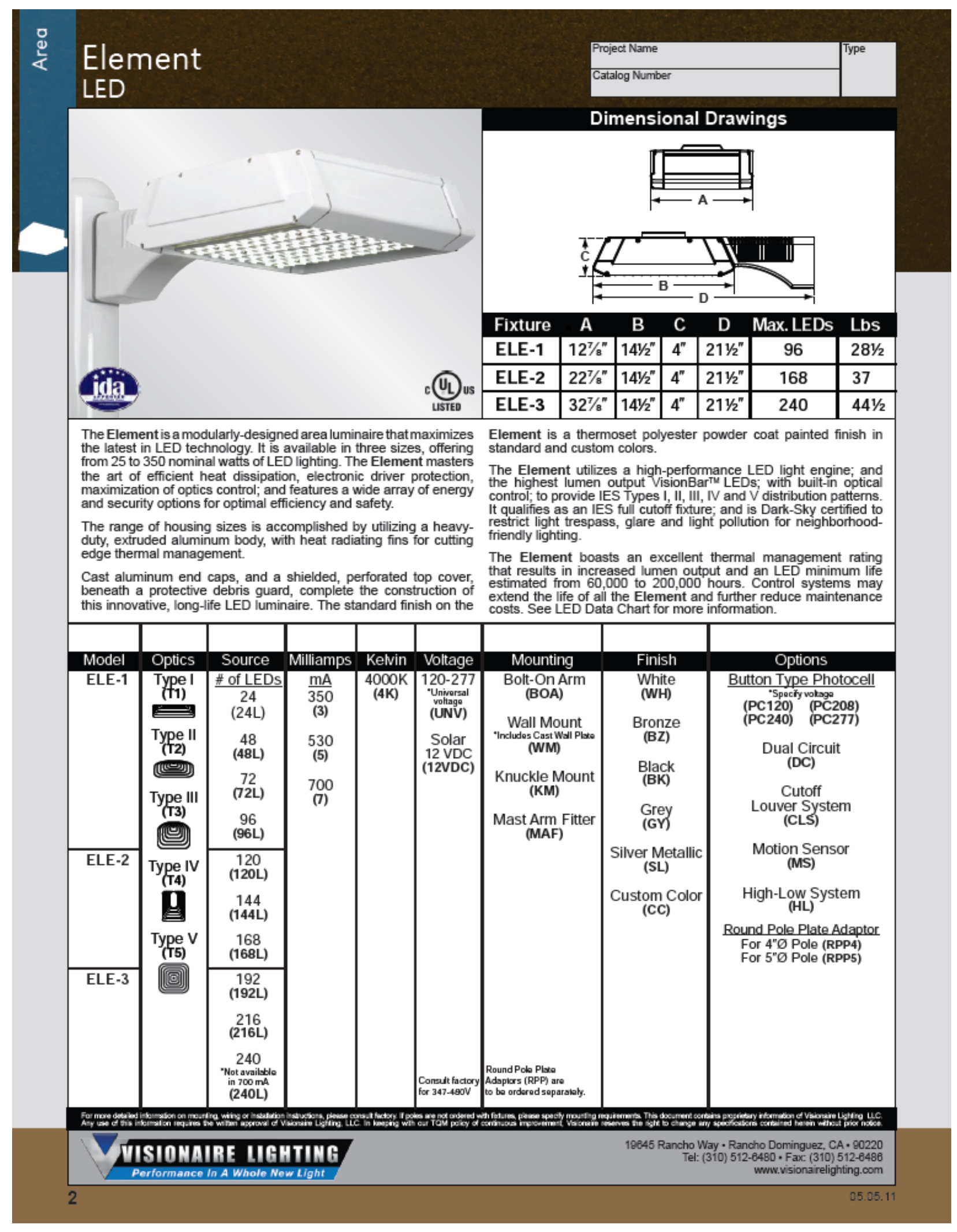




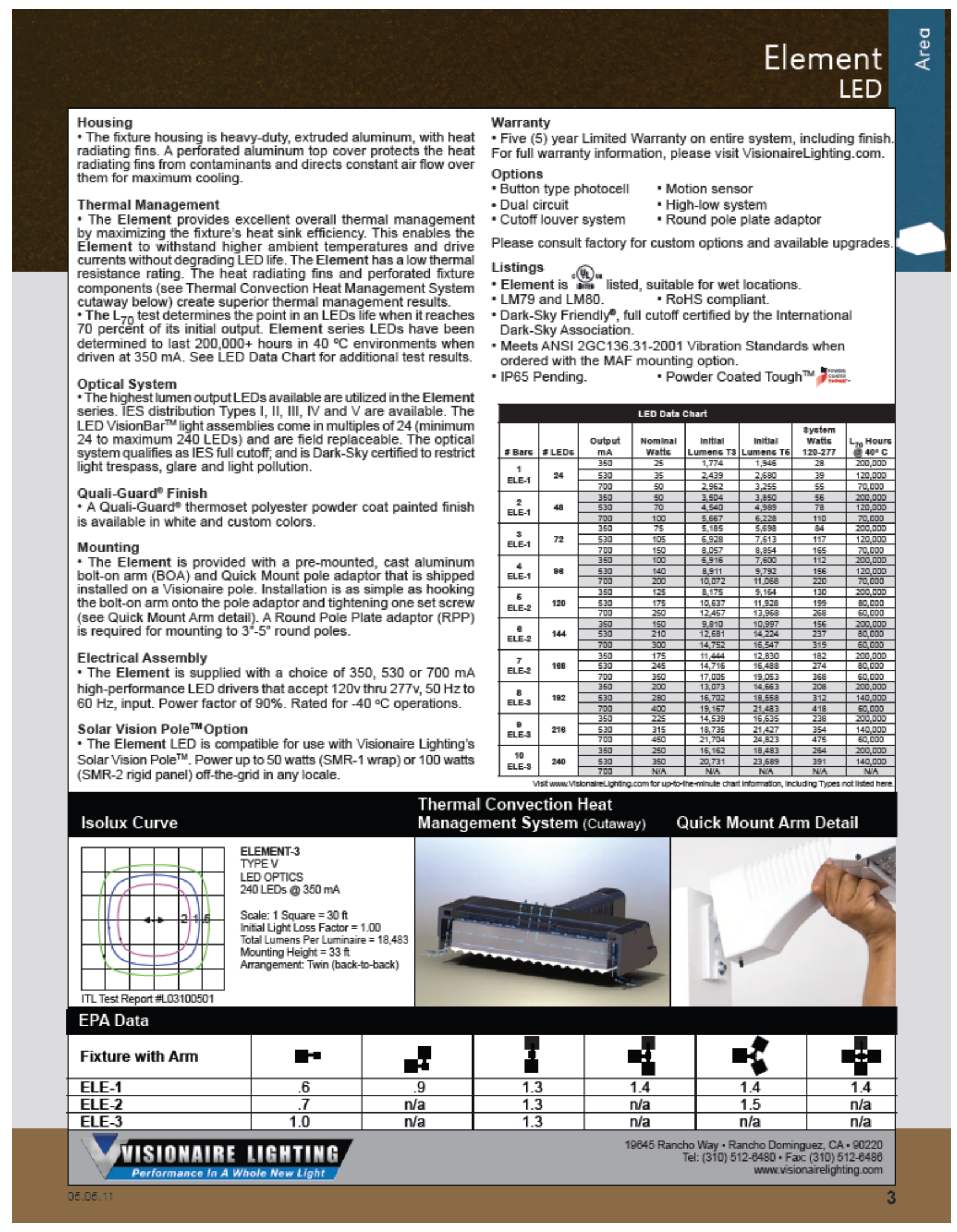



Appendix E

Notes Received from NPS on March 9, 2010 

J Flest zooff of tunNel IS called THE THERESHOCD ZONE. (54) Luminare bulbS 3.7 Feet apart. (44) $400 w$ 米(10) $100 w$ HOS.

everey qtit luminaire is loo watt $\left(5^{\text {th }}\right)$ ?

2) SECOND 250.FT OFTUNAL IS CALLd THE iransction zone. (14) zsow and (13) loow 9.25 FEET APART

1462

(3) The middle section is called the Interior ZONE. (75) 100 WATT 19.5 FEETAPAK

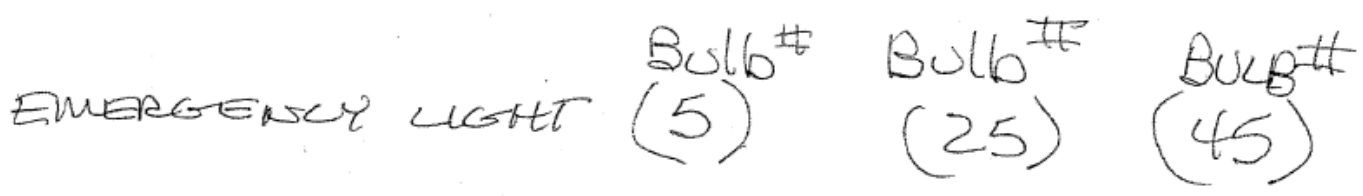

$(44) 400 \mathrm{~W}$

(14) $250 \mathrm{w}$

(14) $250 \mathrm{w}(44) 400$

(10) $100 \mathrm{~W}$

(13) $100 \mathrm{w}$

(75) $100 \mathrm{~W}(13) 100 \mathrm{~W}(10) 100 \mathrm{~W}$

(88) $400 \mathrm{~W}$ 3ultos

(28) $250 \mathrm{w}$ Butbs

121) $100 \mathrm{~W}$ Bulbs

237 BVLBS IN'ALL

TURNEL IS just UNDER $1 / 2$ mile

E.1 
- GE "Tunnel Luminaire" (Gickn)

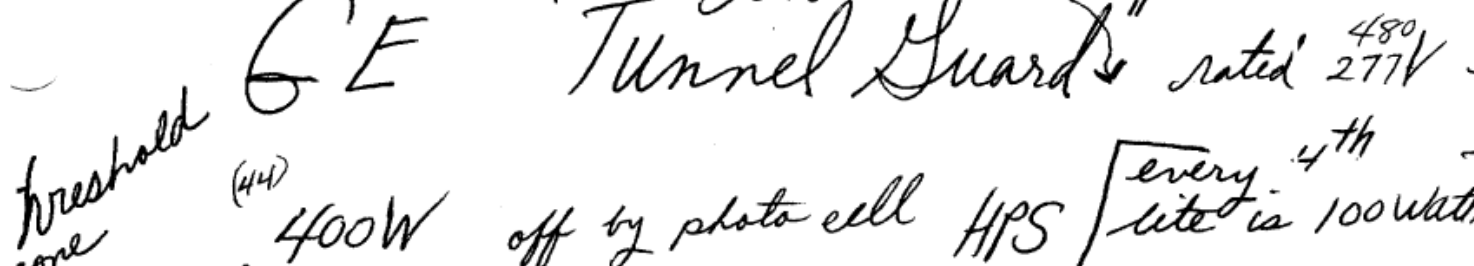

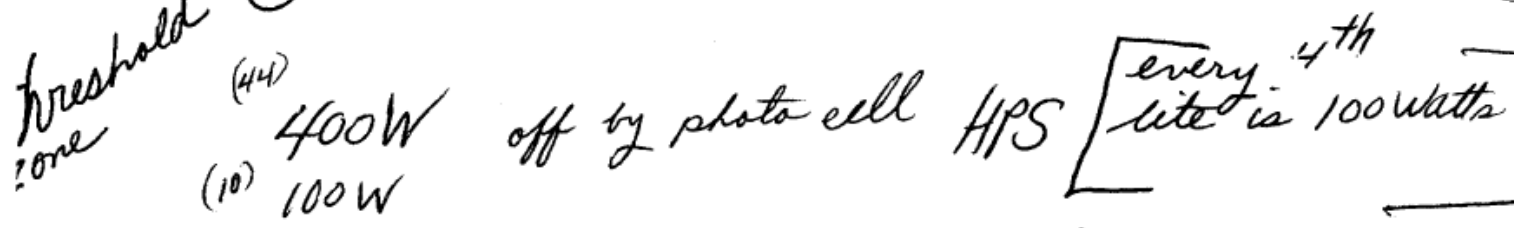

J-Boxed $4 x^{\prime \prime} \times 3^{\prime \prime}$ with $1-1 \frac{1}{2}$ "onduit 6-20A 2P, $480 \mathrm{~V} /$ panels $\angle 1 * \angle 2$

$7-20 \mathrm{~A} 2 \mathrm{P} 480 \mathrm{~V}$ Gor $w$ riveshed $\rightarrow$ Transition.

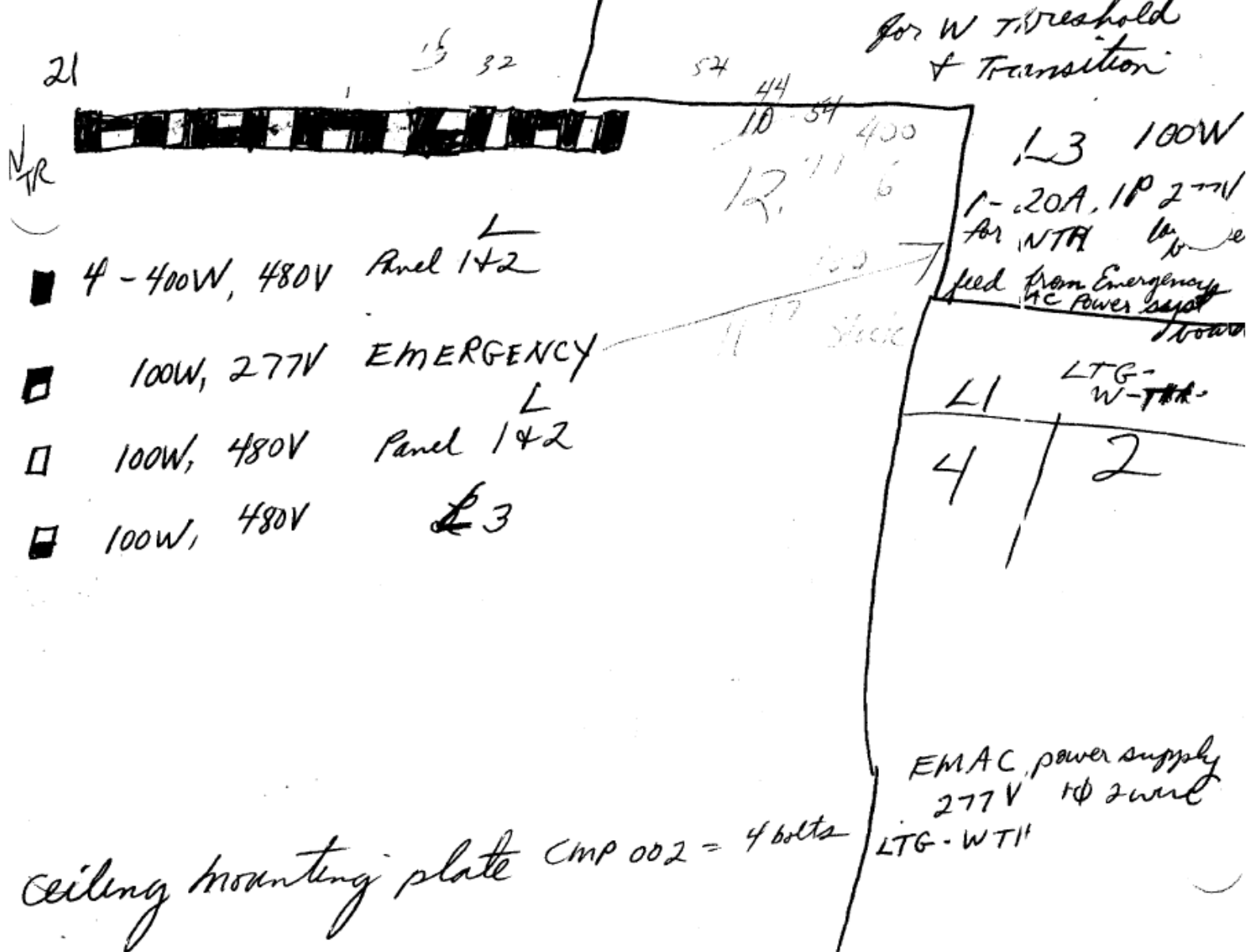

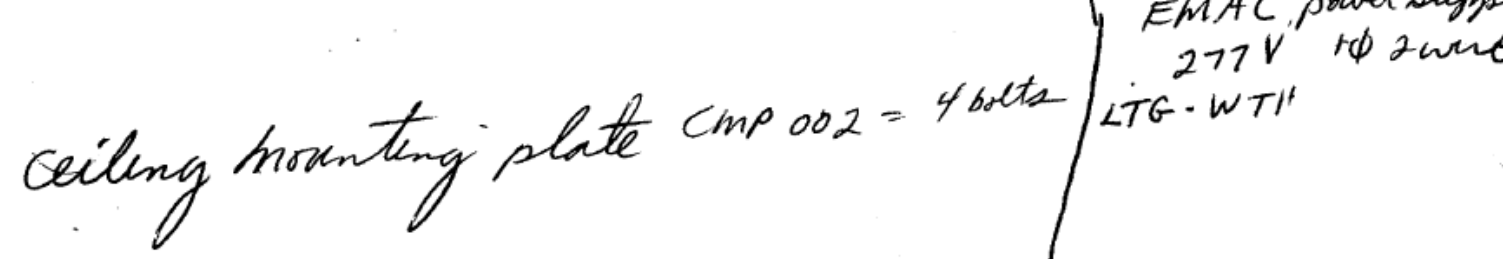

E. 2 



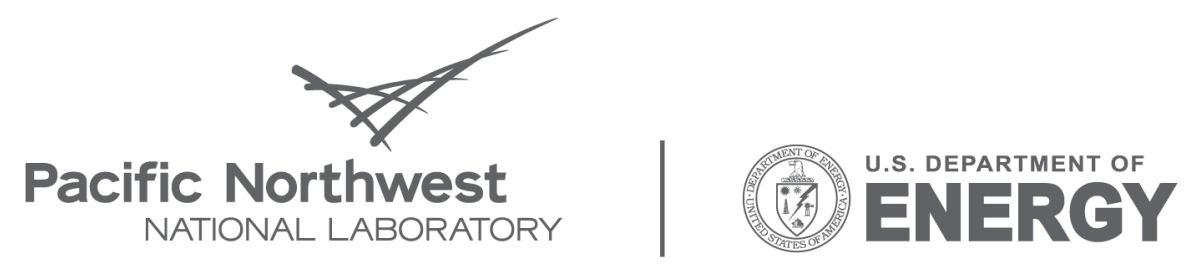

Proudly Operated by Battelle Since 1965

902 Battelle Boulevard

P.O. Box 999

Richland, WA 99352

1-888-375-PNNL (7665)

www.pnl.gov 